\title{
Innovative methods to monitor rock and mountain slope deformation
}

\begin{tabular}{|c|c|}
\hline Journal: & Geomechanik und Tunnelbau - Geomechanics and Tunnelling \\
\hline Manuscript ID & geot.201900074.R1 \\
\hline Wiley - Manuscript type: & Fachthema \\
\hline $\begin{array}{r}\text { Date Submitted by the } \\
\text { Author: }\end{array}$ & $\mathrm{n} / \mathrm{a}$ \\
\hline Complete List of Authors: & $\begin{array}{l}\text { Hormes, Anne; Sky4geo, ; UiT Arctic University of Norway, Department } \\
\text { of Geosciences } \\
\text { Adams, Marc; BFW, Institut für Naturgefahren } \\
\text { Amabile, Anna Sara; Geologische Bundesanstalt, Ingenieurgeologie } \\
\text { Blauensteiner, Franz; Bundesamt für Eich- und Vermessungswesen, } \\
\text { Abteilung Grundlagen } \\
\text { Demmler, Christian; Sky4geo } \\
\text { Fey, Christine; BOKU, Institute for Applied Geology } \\
\text { Ostermann, Marc; Geologische Bundesanstalt } \\
\text { Rechberger, Christina; BOKU, Institute for Applied Geology } \\
\text { Sausgruber, Thomas ; Forsttechnischer Dienst für Wildbach- und } \\
\text { Lawinenverbauung, Geologische Stelle } \\
\text { Vecchiotti, Filippo; Geologische Bundesanstalt, Ingenieurgeologie } \\
\text { Vick, Louise; UiT Arctic University of Norway, Department of Geosciences } \\
\text { Zangerl, Christian; Universität für Bodenkultur Wien, Bautechnik und } \\
\text { Naturgefahren, Institut für Angewandte Geologie }\end{array}$ \\
\hline Keywords: & $\begin{array}{l}\text { slope deformations, rock slides, InSAR - Interferometric synthetic } \\
\text { aperture radar, UAS - unmanned aerial systems, GBInSAR - ground- } \\
\text { based InSAR, UAS photogrammetry }\end{array}$ \\
\hline Subject codes: & $\begin{array}{l}\text { Engineering geology - Ingenieurgeologie, Natural hazards - } \\
\text { Naturgefahren, Measuring technology - Messtechnik }\end{array}$ \\
\hline Abstract: & $\begin{array}{l}\text { Displacement rates of mountain slope deformations that can affect entire } \\
\text { valley mountain flanks are often measured spatially distributed in-situ } \\
\text { without spatial significance. The spatially explicit measurement and } \\
\text { recording of time series of slope deformations is a challenge, as the } \\
\text { unstable slopes are often disintegrated into several subdomains, which } \\
\text { move with different deformation rates. The current state-of-the-art } \\
\text { monitoring systems detect slow to very slow deformation rates between } \\
\text { mm/a and several m/a. We present examples from mountain slope } \\
\text { deformations at Saal-bach-Hinterglemm and the deep-seated rock slide } \\
\text { Marzellkamm in Austria. Terrestrial laser scans provide a level of } \\
\text { detection between } 0.15 \text { and } 0.3 \mathrm{~m} \text {. Extensometer measurements deliver } \\
\text { point measurements with a precision in the mm range. Spaceborne } \\
\text { InSAR gives mm/a precision at } 20 \times 20 \text { m (Sentinel-1) ground sampling } \\
\text { distance (GSD). Unmanned Aerial System Photogramme-try (UAS-P) } \\
\text { delivers orthophotos and digital surface models with lower displacement }\end{array}$ \\
\hline
\end{tabular}




\section{SCHOLARONE $^{\mathrm{M}}$ Manuscripts}

detection limit of $0.05 \mathrm{~m} / \mathrm{a}$. The fixed-point measurements of the Federal Office of Surveying provide in-formation about total slope deformations for the period 1961-2017 with $3.9 \mathrm{~cm}$ to $45.1 \mathrm{~cm}$ with uncertainties of 0$1.5 \mathrm{~cm} / \mathrm{a}$. The different measurements complement each other and are optimally aligned for different application areas. InSAR data can help to identify hot spots on regional and local scale, while UAS-P enables for spatially high level accuracy in the detection of subdomains moving at different speeds. For local warning systems TLS, extensometers and GBInSAR deliver higher accuracy. 
Geomechanik und Tunnelbau Fachaufsatz/Bericht

Prof. Dr. Anne Hormes, Sky4geo, Innsbruck and Arctic University of Norway, Troms $\varnothing$

MSc. Marc Adams, Bundesforschungszentrum für Wald, Innsbruck

MSc. Anna Sara Amabile, Geologische Bundesanstalt, Wien

Dipl. Ing. Franz Blauensteiner, Bundesamt für Eich- und Vermessungswesen, Wien

Christian Demmler, Sky4geo, Innsbruck

Dr. Christine Fey, Universität für Bodenkultur Wien

Dr. Marc Ostermann, Geologische Bundesanstalt, Wien

MSc. Christina Rechberger, Universität für Bodenkultur Wien

Dr. Ing. Mag. Thomas Sausgruber, Wildbach- und Lawinenverbauung, Geologische Stelle, Innsbruck

MSc. Filippo Vecchiotti, Geologische Bundesanstalt, Wien

Dr. Eng. Geol. Louise M. Vick, Arctic University of Norway, Tromsø

Univ.-Prof. Dr. Christian Zangerl, Universität für Bodenkultur Wien

\section{Innovative methods to monitor rock and mountain slope deformation}

Displacement rates of mountain slope deformations that can affect entire valley mountain flanks are often measured spatially distributed in-situ without spatial significance. The spatially explicit measurement and recording of time series of slope deformations is a challenge, as the unstable slopes are often disintegrated into several subdomains, which move with different deformation rates. The current state-of-the-art monitoring systems detect slow to very slow deformation rates between $\mathrm{mm} / \mathrm{a}$ and several $\mathrm{m} / \mathrm{a}$. We present examples from mountain slope deformations at Saalbach-Hinterglemm and the deep-seated rock slide Marzellkamm in Austria. Terrestrial laser scans provide a level of detection between 0.15 and $0.3 \mathrm{~m}$. Extensometer measurements deliver point measurements with a precision in the $\mathrm{mm}$ range. Spaceborne InSAR gives $\mathrm{mm} / \mathrm{a}$ precision at 20x20 m (Sentinel-1) ground sampling distance (GSD). Unmanned Aerial System Photogrammetry (UAS-P) delivers orthophotos and digital surface models with lower displacement detection limit of $0.05 \mathrm{~m} / \mathrm{a}$. The fixed-point measurements of the Federal Office of Surveying provide information about total slope deformations for the period 1961-2017 with 3.9 $\mathrm{cm}$ to $45.1 \mathrm{~cm}$ with uncertainties of $0-1.5 \mathrm{~cm} / \mathrm{a}$. The different measurements complement each other and are optimally aligned for different application areas. InSAR data can help to identify hot spots on regional and local scale, while UAS-P enables for spatially high level accuracy in the detection of subdomains moving at different speeds. For local warning systems TLS, extensometers and GBInSAR deliver higher accuracy. 


\section{Innovative Methoden zur Erfassung von Hangdeformationen}

Bewegungsraten von Hangdeformationen, die ganze Bergflanken betreffen, werden oft ohne räumliche Komponente nur punktuell gemessen. Die räumlich-zeitliche Messung und Aufzeichnung von Hangdeformationen ist eine Herausforderung, da instabile Hänge oft in mehrere Subschollen zerlegt sind. Diese bewegen sich mit unterschiedlichen Bewegungsraten. Die aktuellen hochmodernen Überwachungssysteme erfassen langsame bis sehr langsame Bwegungsraten zwischen sub-mm/Jahr und mehreren $\mathrm{m} / \mathrm{Jahr}$. Wir präsentieren Beispiele für Hangdeformationen in Saalbach-Hinterglemm und die tiefgründige Felsgleitung Marzellkamm in Österreich. Terrestrische Laserscans bieten eine Erfassungsgenauigkeit zwischen 0,15 und 0,3 m. Extensometer-Messungen liefern Punktmessungen mit einer Genauigkeit im mm-Bereich. Spaceborne InSAR bei 20x20 m (Sentinel-1) räumlicher Auflösung ergeben eine Messgenauigkeit von mm/a. Die Drohnen-Photogrammetrie (UAS-P) liefert Orthophotos und digitale Oberflächenmodelle, die Hangdeformationen mit einer Detektionsgrenze von $5 \mathrm{~cm} / \mathrm{Jahr}$ erfassen können. Die Festpunktmessungen des Bundesamtes für Eich- und Vermessungswesen geben Auskunft über die totalen Hangdeformationen für den Zeitraum 1961-2018 mit 3.9-45.1 cm mit einer Unsicherheit von 0-1.5 cm. Die verschiedenen Messungen ergänzen sich gegenseitig und können für verschiedene Anwendungsbereiche optimal aufeinander abgestimmt werden. InSARDaten können helfen, Hot Spots auf regionaler und lokaler Ebene zu identifizierne, während UAS$\mathrm{P}$ eine räumlich hohe Genauigkeit bei der Erfassung von Teilschollen ermöglicht, die sich unterschiedlich schnell bewegen. Für lokale Warnsysteme liefern TLS, Extensometer und GBInSAR eine höhere Genauigkeit.

Keywords: slope deformations, terrestrrial laser scans, InSar (Interferometric synthetic aperture radar), UAS (unmanned aerial systems), GBInSAR (ground-based InSAR), Hangdeformation, terrestrische laserscans, Drohnenphotogrammetrie

\section{Challenges to measure surface displacement rates of slope deformation}

Slope deformations in bedrock are classified as slow to extremely slow moving mountain and rock slope deformations [1]. This type of deformation has been subject to numerous investigations in mountain regions such as Austria, Italy and Norway [2-6]. Still inventories remain incomplete in Europe and pose a risk to mountain societies, as secondary rockfalls and landslides often detach 
from the creeping mass movements [7]. It seems that rockfalls and spontaneous landslides occur unexpectedly and suddenly, but these events are almost always characterized by long periods of deformation. Conditioning factors for failure include the physical material properties of the rocks affected, and the progressive strength degradation of the rock mass over time [8-10]. To determine the state of the deformation within the progressive failure model i.e. if deformation has surpassed the creep phase into the critical acceleration phase, records of displacement rates are required [1113]. Deformation measurements in a time series show whether the slope activities are characterised by acceleration and stabilisation phases and are needed to evaluate the potential hazard of the slope deformation $[11,14,15]$.

More than 300 rock slope deformations have been inventoried in the Austrian Alps with a further 72 deposits from catastrophic rock slope failures identified [16]. The activity status of the slope deformations is often difficult to assign due to the creep movements on a scale of mm-cm/a near the detection limit, and the spatial distribution of deformation across the slope. Monitoring systems are often installed at short notice and only for a limited time if an acute acceleration phase is detected due to infrastructure damage that has already occurred. Since the baseline measurement is then recorded within the acceleration phase and no more measurements are carried out after the phase has decayed, it is difficult to make long-term forecasts [11]. The uncertainty about the activity status of these slope deformations calls for innovative monitoring methods; in addition, current inventory and susceptibility cartography must be updated to ensure regions are adequately prepared and able to respond [7, 11, 17]. In order to set up Early Warning Systems (EWS) for complex landslides it is critical to retrieve a deeper understanding of the internal deformation and behaviour of the different subdomains and therefore a spatial monitoring system [12]. Measuring and interpreting single points on the surface of slope deformations has the inherent problem that only small or localised instability, or displacement of only a single subdomain may be detected. The need to clarify the spatial development of an entire slope over time calls for innovative monitoring methods, which have area-wide coverage and can be complimentary to the traditional fixed point surveying methods such as dGNSS (differential Global Navigation Satellite Systems) and tachymetric measurements. The article presents the recent developments to improve spatial and temporal monitoring of slope deformation to automatically generate surface change models, displacement rates and vectors. Accurate monitoring of areal deformations requires several parallel systems, such as Interferometric Synthetic Aperture Radar (InSAR) from satellite data, groundbased InSAR (GBInSAR) and unmanned aerial systems photogrammetry (UAS-P) [18-21]. Several high risk slope deformation sites in Norway such as Mannen, Åknes, Hegguraksla, Joasetbergi, Jettan and Indre Nordnes are long-term monitored with a combination of tilt meters, 
extensometers, dGNSS, laser, GB-InSAR, satellite-based InSAR [15, 22-24]. In Italy a similar combination of fixed point data measures and remote sensing methods is in use [25]. The experience gained in Italy and Norway in recent years with this combination of different measurement methods can serve as model for a better detection and possible monitoring of acceleration of slope displacements in Austria [11,26].

It is therefore critical to consider a) the measure of fixed points with high temporal resolution distributed over the entire slope (dGNSS, extensometers), b) the use of remote sensing methods to capture the spatial variability of displacement with terrestrial laser scanning / aerial laser scanning (TLS/ALS), GBInSAR, satellite-based InSAR and unmanned aerial systems photogrammetry (UAS-P) c) to complement displacement rate data with deformation data of the interior body using inclinometers, extensometers, Differential Monitoring Systems (DMS columns), temperature loggers and piezometers, geophysical data and d) the kinematic mechanism of the slope deformation.

Our method development is part of the Sky4geo research project "Vigilans - Monitoring slope deformations with InSAR and unmanned aerial vehicle photogrammetry" funded by the Austrian Research Promotion Agency Space Program (FFG ASAP) [27]. Here, we present displacement time series from two test sites of our project: in Saalbach-Hinterglemm from InSAR and the geodetic fixed point surveying time series; at Marzellkamm (Inner Ötztal) from unmanned aerial system photogrammetry (UAS-P), extensometer, terrestrial laser scanning (TLS) and dGNSS (Figure 1). The slope deformation Marzellkamm is characterised by a head scarp, several minor scarps, trenches, graben and increasing rockfall activity [28]. It covers an area of $0.24 \mathrm{~km}^{2}$ between 2450 and $2850 \mathrm{~m}$ a.s.1. in paragneisses, mica schists and banded amphibolites with a primary foliation dipping moderately towards SE on slopes facing towards SE-E with angles of 30-80 [29]. Annual displacement rates of six identified different subdomains or rock slide slabs [30] were measured in the years 1971-2009 with orthoimages, 2006-2010 with airborne laser scans, 20122019 with differential GNSS and geodetic surveys, 2014 and 2019 with terrestrial laser scans. Saalbach-Hinterglemm is well known for several instable slopes.

The need for increased monitoring data for slope deformations is two-fold: 1) detect slope deformations and improve existing inventories as these are incomplete, and 2) retrieve temporal and spatial monitoring data as a crucial input to evaluation of the activity status for hazard analysis. Obtaining these data will help to improve the current model of Austrian slope deformations, in turn improving existing Early Warning Systems (EWS) [11, 14, 31]. In this paper we focus on highprecision fixed point and block displacement measures, as well as recent developments in remote 
Geomechanik und Tunnelbau Fachaufsatz/Bericht

sensing techniques to obtain a full spatial coverage. The combination of techniques provides users with a multi-aspect data repository and the means by which to verify the different data against each other.

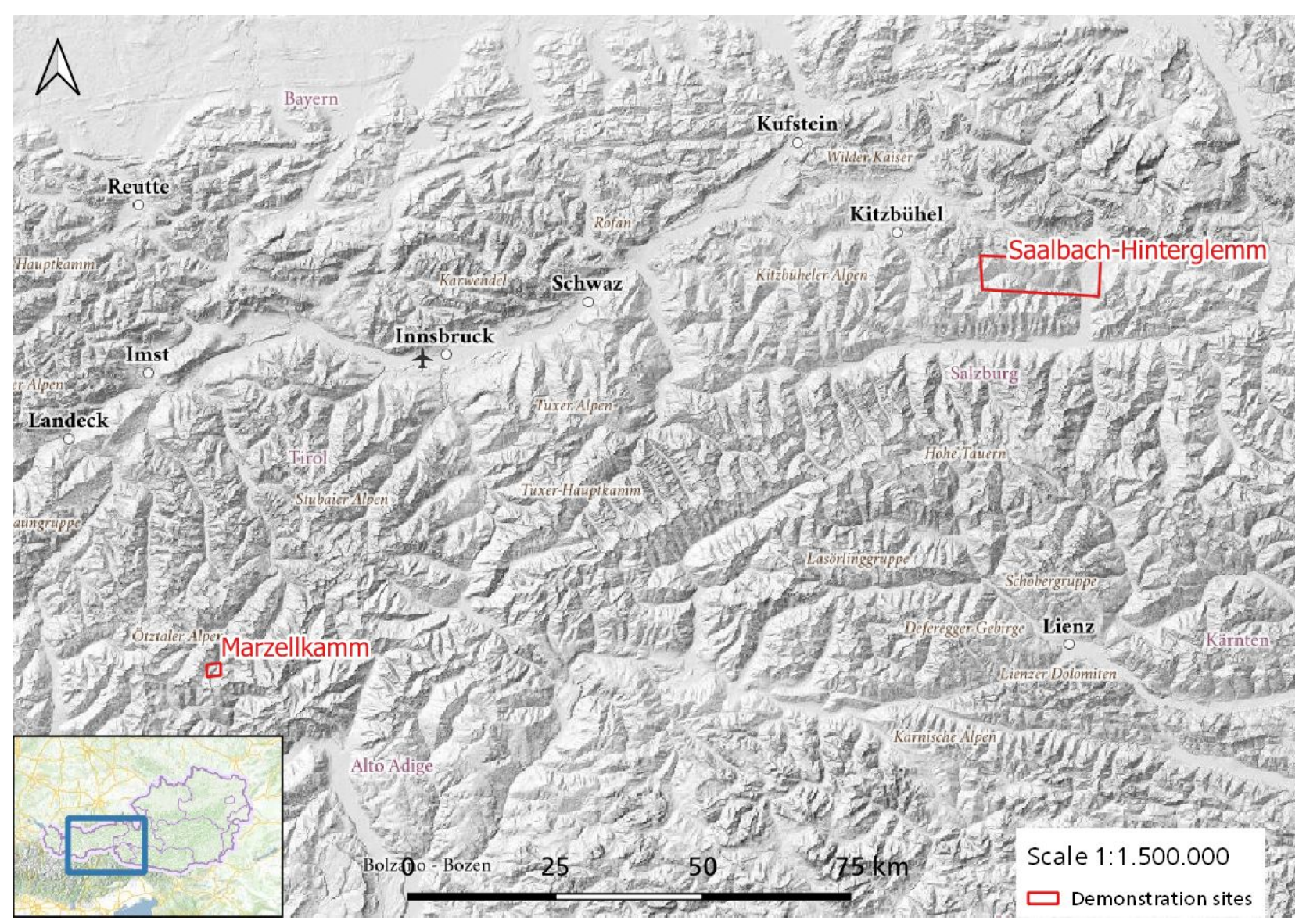

Figure 1 Overview map of Tyrol and Salzburg in Austria with two slope deformation sites at Marzellkamm (Inner Ötztal) and the Saalbach-Hinterglemm (Salzburger Land) area presented in the text.

Bild 2 Übersichtskarte von Tirol in Österreich mit den im Text vorgestellten Beispielen der Hangdeformationen in Saalbach-Hinterglemm (Salzburg county) und Marzellkamm (Inner Ötztal).

\section{Geodetic fixed point surveying time series}

A fixed point in geodesy is a stable surveying point that fulfills both of the following conditions: The point is known in coordinates from a previous survey (by location and/or height) and the point is permanently marketed (stabilised) in nature. Fixed points serve as reference points for surveys of all kinds. The use of the nearest fixed points and their coordinates in Austria is even legally binding for cadastral plans documents [1]. To determine the coordinates of the fixed points in the modern European reference system ETRS89, not only all GPS vectors measured so far are used, but also all terrestrial observations measured since 1906, i.e. direction, elevation angle and distance measurements [32]. For each point, all available measurements are processed and fed 
into a network compensation [32].

Fixed points should be stable, but this is not always the case, because fixed points, besides other factors, are often influenced by gravitational mass movements in their spatial position. By analysing the results of the individual fixed-point surveying epochs, conclusions can be drawn about possible deformation rates of gravitational mass movements after excluding possible sources of error (Figure 2, Table 1) [1]. Thus for each individual epoch and for each point the coordinate in the ETRS89 system is determined and from the changes between the epochs vectors are calculated which can be regarded as motion vectors of mass movements (Figure 2, Table 1). Statements about motion rates can be made retroactively up to the year of the origin of the point concerned [32]. In Saalbach-Hinterglemm (Figure 1) fixed points from BEV have been installed since 1961 (1961: 2 points; 1968: 1 point; 1981: 9 points; 1986: 1 point) and have been re-measured in different intervals. The total displacement of the fixed points varies from $0.4-16.8 \mathrm{~cm}$ in $\mathrm{Y}$ direction, from 3.2 to $12.4 \mathrm{~cm}$ in X-direction and from 2.3-12.8 cm in Z-direction (Table 1). Concerning the period from installation to re-measurement mean annual displacement values can be calculated. These values range from $0.1-1.1 \mathrm{~cm} / \mathrm{a}$ in Y-direction, from $0.2-0.7 \mathrm{~cm} / \mathrm{a}$ in $\mathrm{X}-$ direction and from $0.1-0.8 \mathrm{~cm} / \mathrm{a}$ in Z-direction (Table 1).

One point has been re-measured four times since its installation in 1961 (2201 in Figure 2) and shows a total displacement in Y-direction of $24.5 \mathrm{~cm}$, a total displacement in X-direction of 29.9 $\mathrm{cm}$ and a total displacement in Z-direction of $20 \mathrm{~cm}$ (Point number 2201, 3201, 4201, 5201 in Table 1). The point also shows some changes in the displacement vector direction.

The resulting total vectors of point displacement range from $3.9 \mathrm{~cm}$ to $45.1 \mathrm{~cm}$ in the period 1961 2017. One fixed point (5205 in Figure 2) shows some increase of elevation (total: $2.3 \mathrm{~cm}$; mean annual: $0.1 \mathrm{~cm}$ ) which might be related to toe bulging. 

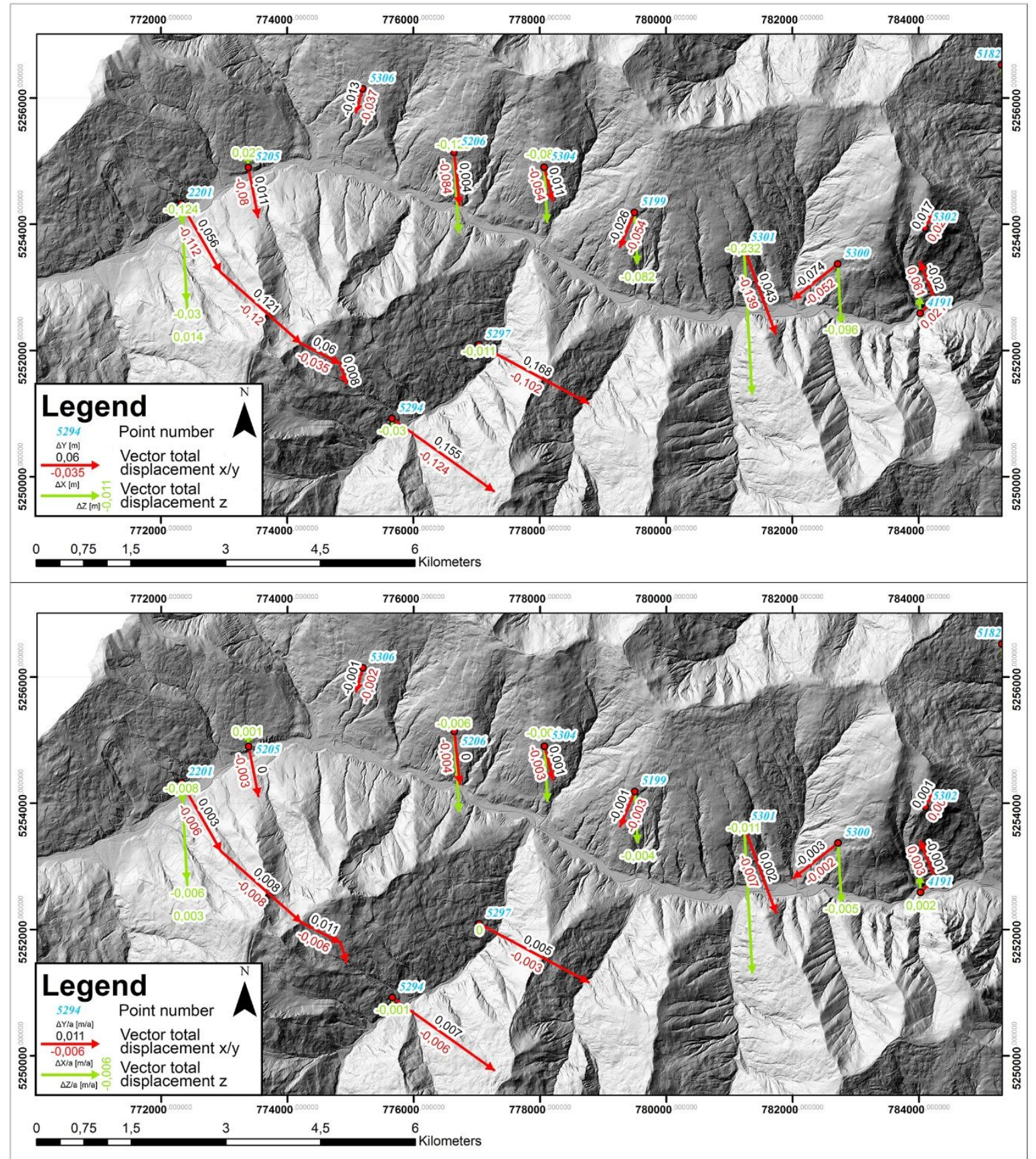

Figure 2 a) Hillshade image of the Glemm Valley (SAGIS) with indicated surveying points (BEV) and total vectors in X/Y direction (red arrows) and displacement vectors in $Z$ direction (green arrows). The black numbers give the displacement in $Y$-direction in centimetres (pos. = towards East, neg. = towards West), the red numbers the displacement in X-direction (pos. = towards North, neg. = towards South) and the green number the change in elevation (pos. $=$ up, neg. $=$ down).

b) Hillshade image of the Glemm Valley (SAGIS) with indicated surveying points (BEV) and total vectors in X/Y direction (red arrows) and displacement vectors in $Z$ direction (green arrows). The black numbers give the mean annual displacement in $Y$-direction in centimetres (pos. = towards East, neg. = towards West), the red numbers the mean annual displacement in $X$-direction (pos. = towards North, neg. $=$ towards South) and the green number the mean annual change in elevation (pos. = up, neg. = down).

Bild $2 \quad$ a) Hillshade-Darstellung des Glemmtals (SAGIS) mit eingezeichneten Vermessungspunkten (BEV) und Verschiebungsvektoren in X/YRichtung (rote Pfeile) und Verschiebungsvektoren in Z-Richtung (grüne Pfeile). Die schwarzen Zahlen geben die Verschiebung in Y-Richtung in Zentimeter an (Pos. = nach Osten, neg. = nach Westen), die roten Zahlen die Verschiebung in X-Richtung (Pos. = nach Norden, neg. $=$ nach Süden) und die grüne Zahl die Höhenänderung (pos. = nach oben, neg. = unten).

b) Hillshade-Darstellung des Glemmtals (SAGIS) mit eingezeichneten Vermessungspunkten (BEV) und den Verschiebungsvektoren in X/Y-Richtung (rote Pfeile) und Verschiebungsvektoren in Z-Richtung (grüne Pfeile). Die schwarzen Zahlen geben die mittlere jährliche Verschiebung in Y-Richtung in 

nach Süden) und die grüne Zahl die mittlere jährliche Höhenänderung (pos. = oben, neg. = unten).

Overall the fixed point measurements of BEV represent a high quality and long term dataset that stands for its own and can support other slope monitoring methods in areas nearby the populated valley bottoms. The interpretation of the dataset concerning slope deformations is not trivial, but can deliver information of the range of movements over decades with uncertainties of $0-1.5 \mathrm{~cm}$ (Table 1).

Table 1 Total displacement of the fixed points in y-x-z-direction and mean annual displacement in $y$-x-z-direction. The beginning of the measurement of the fixed points varies (1961-1986) as do the measurement periods and measurement intervals. Therefore, only average values can be given.

Tabelle 1. Absolute Verschiebungsbeträge der Fixpunkte in y-x-z-Richtung und durchschnittliche jährliche Verschiebung in y-x-z-Richtung. Der Beginn der Einmessung der Festpunkte variieren (1961-1986) genauso wie die Messzeiträume und Messzeitabstände. Daher können leider nur Durchschnittswerte angegeben werden.

\begin{tabular}{|c|c|c|c|c|c|c|}
\hline NUMMER & $\Delta Y$ & $\Delta \mathrm{X}$ & $\Delta \mathrm{Z}$ & $\Delta \mathrm{Y} / \mathrm{a}$ & $\Delta \mathrm{X} / \mathrm{a}$ & $\Delta \mathrm{Z} / \mathrm{a}$ \\
\hline Point number & $\begin{array}{l}\text { total point } \\
\text { displacement in } \\
\text { Y-direction (pos. } \\
=\text { towards East, } \\
\text { neg. = towards } \\
\text { West) }[\mathrm{cm}]\end{array}$ & $\begin{array}{l}\text { total point } \\
\text { displacement in } \\
\text { X-direction (pos. } \\
=\text { towards North, } \\
\text { neg. = towards } \\
\text { South) }[\mathrm{cm}]\end{array}$ & $\begin{array}{l}\text { total point } \\
\text { displacement in } \\
\text { Z-direction (pos. } \\
=\text { up, neg. = } \\
\text { down) }[\mathrm{cm}]\end{array}$ & $\begin{array}{l}\text { mean annual } \\
\text { point } \\
\text { displacement in } \\
\text { Y-direction (pos. } \\
=\text { towards East, } \\
\text { neg. = towards } \\
\text { West) [cm/a] }\end{array}$ & $\begin{array}{l}\text { mean annual } \\
\text { point } \\
\text { displacement in } \\
\text { X-direction (pos. } \\
=\text { towards North, } \\
\text { neg. = towards } \\
\text { South) [cm/a] }\end{array}$ & $\begin{array}{l}\text { mean annual } \\
\text { point } \\
\text { displacement in } \\
\text { Z-direction (pos. } \\
=\text { up, neg. = } \\
\text { down) }[\mathrm{cm} / \mathrm{a}]\end{array}$ \\
\hline 5199 & $-2,6$ & $-5,4$ & $-8,2$ & $-0,1$ & $-0,3$ & $-0,4$ \\
\hline 3201 & 5,6 & $-11,2$ & $-3,2$ & 0,3 & $-0,6$ & $-0,2$ \\
\hline 4201 & 12,1 & -12 & $-12,4$ & 0,8 & $-0,8$ & $-0,8$ \\
\hline 5201 & 6 & $-3,5$ & -3 & 1,1 & $-0,6$ & $-0,6$ \\
\hline 2201 & 0,8 & $-3,2$ & 1,4 & 0,2 & $-0,6$ & 0,3 \\
\hline 5205 & 1,1 & -8 & 2,3 & 0 & $-0,3$ & 0,1 \\
\hline 5206 & 0,4 & $-8,4$ & $-12,8$ & 0 & $-0,4$ & $-0,6$ \\
\hline 5294 & 15,5 & $-12,4$ & -3 & 0,7 & $-0,6$ & $-0,1$ \\
\hline 5297 & 16,8 & $-10,2$ & $-1,1$ & 0,5 & $-0,3$ & 0 \\
\hline 5300 & $-7,4$ & $-5,2$ & $-9,6$ & $-0,3$ & $-0,2$ & $-0,5$ \\
\hline 5301 & 4,3 & $-13,9$ & $-23,2$ & 0,2 & $-0,7$ & $-1,1$ \\
\hline 5304 & 1,1 & $-5,4$ & $-8,8$ & 0,1 & $-0,3$ & $-0,4$ \\
\hline 5306 & $-1,3$ & $-3,7$ & 0,2 & $-0,1$ & $-0,2$ & 0 \\
\hline
\end{tabular}

\section{$3 \quad$ InSAR}

Detecting ground deformation using multi temporal satellite interferometric radar techniques (InSAR) has been established as nationwide services in Italy and Norway [33, 34]. The services provide ground motion detection and monitoring on a wide area for slow-moving landslides based on Persistent Scatterer Interferometry (PSI) or small baseline subset techniques (SBAS) $[35,36]$. InSAR provides an important tool to spatially detect precursory movements that might cause a rock slope failure to prevent loss of lives. The most critical landslides can be traced using ground-based InSAR to an accuracy of sub millimetres $[22,25,37]$. Another crucial strength of InSAR is the 
capability of analysing slope behaviour even retrospective, i.e. by analysing available SAR data such as Sentinel-1 (since 2014), TerraSAR-X (TSX) (2014-2016) and ENVISAT (2004-2010) covering time spans of some decades back, since information on past slope behaviour is a crucial input for sound stability prognoses.

The SAR-principle is based on actively transmitting electromagnetic microwaves and analysing its echo [38-40]. These microwaves penetrate clouds and are able to capture data during the night, although the recorded signal depends strongly on the complexity of the recorded terrain as the recorded image is taken at $90^{\circ}$ of the flight path (i.e. Line of Sight $(\operatorname{LoS})$ [41]. The phase of the reflected signal is related to the distance of the sensor to the target, and the spatial resolution of SAR depends on the sensor used, the band width (e.g. X-, L-, C-bands) and the difference in azimuth and range direction used. In our example in Saalbach-Hinterglemm we show some results from the $\mathrm{C}$-band with wave lengths of $\lambda=5-6 \mathrm{~cm}$. Differential InSAR-techniques can detect ground deformations by processing the interferogram, or phase difference in the electromagnetic spectrum of two SAR images acquired over the same area at different time steps, thus allowing to detect displacements in the range of few millimetres. The new generation of satellite missions, including Sentinel-1 and TerraSAR-X, are able to detect maximum velocities of up to $160 \mathrm{~cm} / \mathrm{a}$ [40].

The most promising time series analyses for surface deformation in mountainous regions are PSI/IPTA (Persistant Scatterer Interferometry/Interferometric Point Target Analysis) and multidimensional SBAS (MSBAS [42-45]. Both techniques are using differential InSAR (DInSAR) using phase changes between two images in a given time to monitor lateral deformation, by filtering the topographic phase using a reference DEM. We present here some results for one of our study areas in Saalbach-Hinterglemm (Figures 1,3,4).

During the Vigilans project a so called "a priority PS density map" was produced incorporating for the first time a variable viewing angle into the model for Sentinel-1 and TSX over Austria (Figure 3). A priori density map simulates the PSI visibility determining the areas affected by layover and foreshortening. This a priori PSI density map at $10 \mathrm{~m}$ resolution was compiled by adopting the new land cover product available (LISA) and the Copernicus CORINE $100 \mathrm{~m}$ resolution product [46, 47]. For Sentinel-1 and TerraSar- $X$ a complete workflow to produce the visibility maps was developed within SNAP (ESA's SentiNel Application Platform) and ArcGIS. 
PS Density map for Sentinel-1 in Descending Orbits

Full deformation Partial deformation

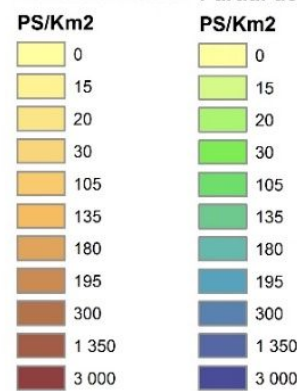

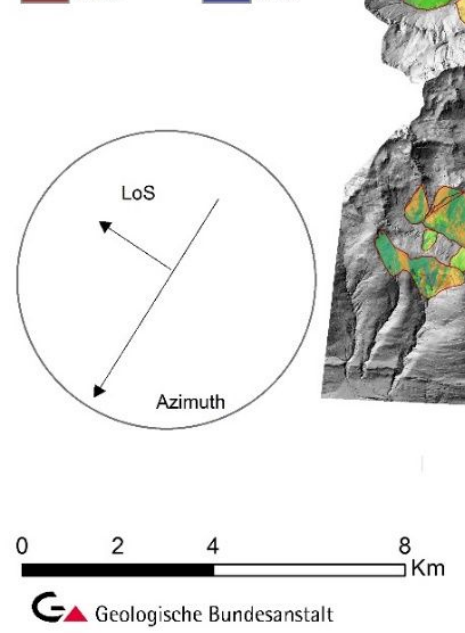

Figure 3 PSI density map of the second generation of the Saalbach-Hinterglemm region highlighting the visibility of potential slope deformation areas with Sentinel-1 in descending orbit acquisition. Density means the probable number of PS per square Kilometres retrievable by taking into account the negative effects of layover and foreshortening. Green-blue colours represent the slopes where only a portion of the deformation signal can be computed; yellow-brown colours are the most suitable sites to recover the full deformation signal with the DInSAR technique [48].

Bild 3 PSI-Dichtekarte der zweiten Generation der Region Saalbach-Hinterglemm, die die Sichtbarkeit potenzieller Hangdeformationsbereiche mit Sentinel-1 bei der absteigenden Orbit-Erfassung hervorhebt. Dichte bedeutet die mögliche Anzahl von PS pro Quadratkilometer, die unter Berücksichtigung der negativen Auswirkungen des „Layover“ und „Foreshortening“ abrufbar ist. Grün-blaue Farben stellen die Hänge dar, an denen nur ein Teil des Verformungssignals berechnet werden können; gelb-braune Farben sind die am besten geeigneten Stellen, um das vollständige Verformungssignal mit der DInSAR-Technik darzustellen [51].

A PSI and SBAS Stamps (Stamps is a software package by University of Leeds) workflow for the identification of coherent points for surface deformation analysis was used for the processing of Envisat data in descending orbits [49]. The temporal stack for Saalbach-Hinterglemm is composed of 22 Envisat scenes from the descending orbit (track 394) acquired between 26.01.2004 and 28.06.2010. For the recent temporal stack of Sentinel-1 the Multidimensional small baseline subset algorithm (MSBASv3) on 77 Sentinel-1 scenes acquired between 11.01.2017 and 02.03.2019 on descending orbit track 95 was instead used $[45,50]$. The MSBAS algorithm is a powerful tool that allows the simultaneous inversion of unwrapped and de-ramped stack of interferograms acquired

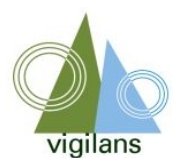


in ascending and descending orbits, in order to derive East-West and Up-Down components from the Line of Sight vector of deformation velocity [45]. The MSBAS delivers a linear Time Series with error bars for each point. The results for descending orbits (D_95) for Sentinel-1 and the results for the descending orbits for Envisat (D_394) in line of sight are shown in Figure 4. The stability threshold (the green colours points) was chosen as 1 time the standard deviation of the velocity along the line of sight for the Envisat data (the above $-3.1 \mathrm{~mm} / \mathrm{a}$ ) and $+8 \mathrm{~mm} / \mathrm{a}$ which corresponds to the standard deviation of the velocity field for the Sentinel-1 dataset [51].

In order to compare the interferometric analysis with the geodetic point displacement only the updown and the east-west component of the movement is taken into account. Since only the descending orbit data was processed, the displacement towards the east cannot be compared with the persistent scatters. In order to extract the negative vertical component, the measurement of the interferometric points must be multiplied by the cosine vertical vector [52-54]. Therefore, the vertical component of the fixed points 5301, 5304, 5306 and 2201 in Figure 4 can be used as validation thanks to the favourable exposition of the slopes and the vicinity of clusters of homogeneous Sentinel-1 instable scatters.

Most of the Envisat results show absolutely no movement (2004-2010) for the nine monitoring stations highlighted here. Only fixed point number 5301 shows a maximum vertical with $-11 \mathrm{~mm} / \mathrm{a}$, which is in agreement with the MSBAS displacement of $-15.4 \mathrm{~mm} / \mathrm{a}$ in the line of sight, corresponding to a $-11.4 \mathrm{~mm} / \mathrm{a}$ in vertical displacement. Another good agreement between geodetic and SAR interferometric measurements can be seen at the location of the BEV point number 2201 which lays at the bottom of the well known instable slope of Sonnalm, directly above the town of Hinterglemm. The most recent vertical displacement of $-6 \mathrm{~mm} / \mathrm{a}$ measured at BEV point agrees with the Sentinel-1 cluster of three yellow squares with a line of sight $-8.7 \mathrm{~mm} / \mathrm{a}^{-1}$ measurement (vertical equivalent $-6.6 \mathrm{~mm} / \mathrm{a}$ ). Last but not least the geodetic point number 5306 with a west component of $-2 \mathrm{~mm} / \mathrm{a}^{-1}$ matches closely to the cluster of yellow square MSBAS values in LoS (varying between -3.7 and $-4.9 \mathrm{~mm} / \mathrm{a}$ ) and the point number 5304 with a vertical of $-4 \mathrm{~mm} / \mathrm{a}$ and nearby orange scatters with a LoS of -11.4 (vertical equivalent of $-8.7 \mathrm{~mm} / \mathrm{a}$ ).

For a more exhaustive study of the complex behaviour of those highlighted instable slopes the use of the time series will contribute to the better understanding of meteorological and seasonal effects on local displacements. Moreover, the combination of both orbits will allow for a better comparison between pure east-west and up-down components of radar interferometric data against geodetic points. 


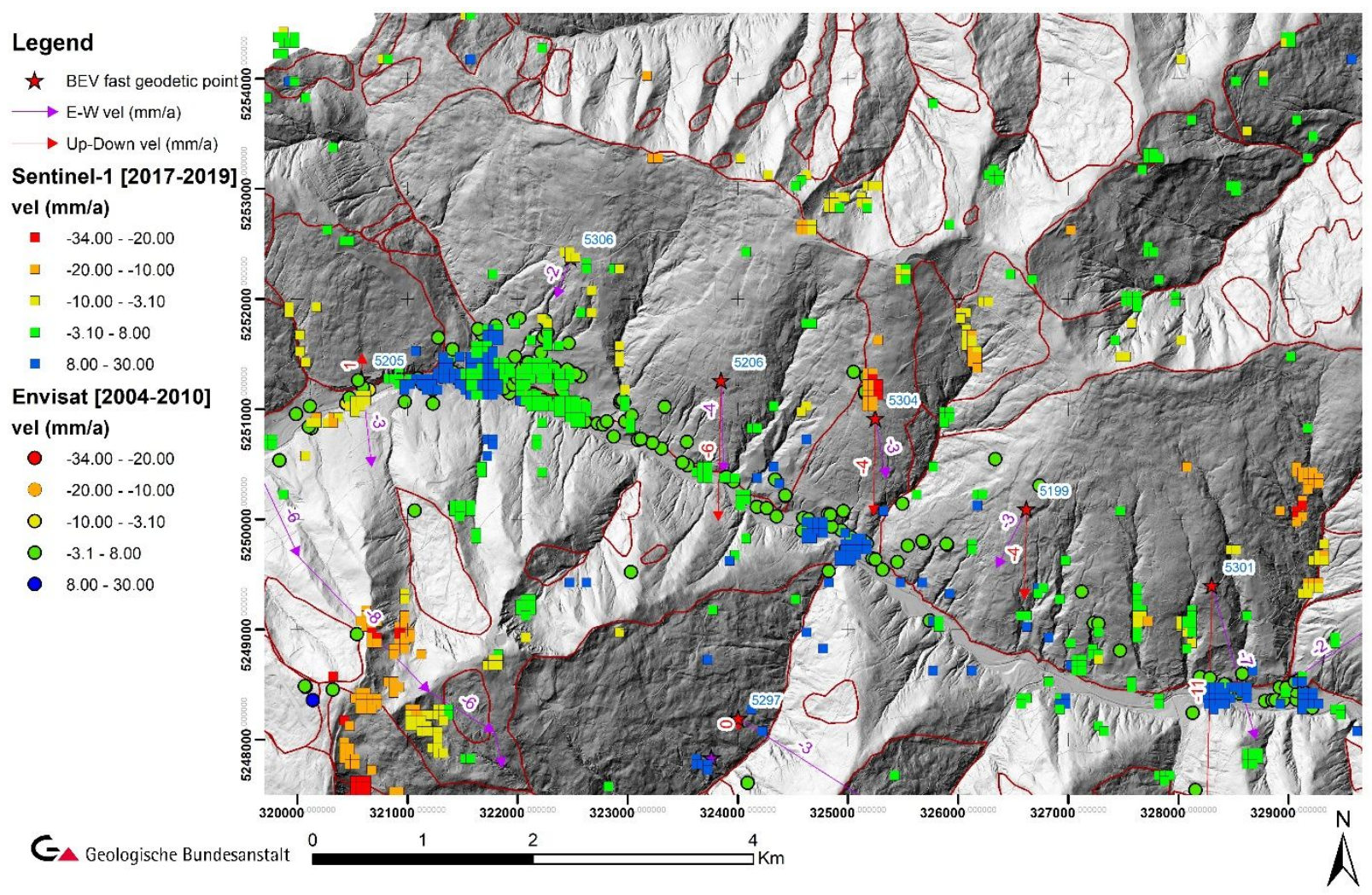

Figure 4 Fixed geodetic points from BEV compared to StamPS SBAS results using 2004-2010 Envisat data (points, geocoding resolution $20 \times 20 \mathrm{~m}$ ) and MSBAS results using 2017-2019 Sentinel-1 data (squares, geocoding resolution $50 \times 50 \mathrm{~m}$ ) in descending geometry. The stability threshold was chosen as 1 standard deviation of the velocity along the line of sight for the Envisat data $-3.1 \mathrm{~mm} / \mathrm{a}$ and $+8 \mathrm{~mm} / \mathrm{a}$ for Sentinel-1.

Bild 4 Geodätische Punkte von BEV im Vergleich zu StamPS SBAS-Ergebnissen mit Envisat-Daten 2004-2010 (Geokodierungsauflösung $20 \times 20 \mathrm{~m}$ ) und MSBAS-Ergebnissen mit Sentinel-1-Daten 2017-2019 (Geokodierungsauflösung 50 × 50 m) in absteigender Geometrie. Der Stabilitätsschwellenwert wurde als 1 Standardabweichung der Geschwindigkeit entlang der Sichtlinie für die Envisat-Daten -3,1 mm/a und +8 mm/a für Sentinel-1 gewählt.

\section{GBInSAR}

Ground Based Synthetic Aperture Radar Interferometry (GBInSAR) is an innovative remote sensing technique that allows to derive multi-temporal surface deformation maps suitable for monitoring the complex distribution of displacement fields with a high spatio-temporal resolution and an excellent accuracy and precision across slope deformation bodies $[22,55,56]$. In particular, it allows the detection of displacement components along the sensor-target LoS with a precision range from sub-mm to a few $\mathrm{mm}$ and a spatial resolution with typical values of few meters at a range of some kilometres up to few $\mathrm{cm}$ at a range of some tens of $\mathrm{m}$ [57]. The range of displacement velocity that can be investigated varies from few $\mathrm{mm} / \mathrm{a}$ up to one $\mathrm{m} / \mathrm{h} \mathrm{[56]}$. Depending on the velocity of the observed slope deformation, the ground-based radar sensor can be used in two types of acquisition mode: continuous (C-GBInSAR) and discontinuous (D-GBInSAR). In general, for 
a range of displacement rates from some $\mathrm{mm} / \mathrm{d}$ to $\mathrm{m} / \mathrm{d}$ permanent monitoring through continuous observations are to prefer. On the other hand, D-GBInSAR acquisitions can be carried out for slower phenomena where C-GBSAR monitoring is not possible for logistical or cost reasons [56]. The flexibility of the ground-based radar allows to overcome most of the drawbacks linked to spaceborne interferometry. In fact, for GBInSAR the approach allows to change the observation parameters (e.g. acquisition geometry, observation frequency, revisiting time) in order to accomplish the specific characteristics of the slope process (variability in terms of size, movement mechanism, displacement rate, state and distribution of activity). The main drawbacks of GBInSAR are the strong influence of vegetation, limiting the application to bare rock or sparse vegetated slopes.

The device used within the Vigilans project is the GBInSAR Lisamobile system (Ellegi Ltd.), a Linear SAR that provides measurements at $\mathrm{Ku}$ frequency band (central frequency: $17.2 \mathrm{GHz}$; wavelength: $17.44 \mathrm{~mm}$ ) with a synthetic aperture of up to $3 \mathrm{~m}$ (Figure 5). The system operates also at long-range, with an average operative distance of about $2 \mathrm{~km}$ and a maximal distance of about 4 $\mathrm{km}$ without limitations due to atmospherical conditions [58]. In C-GBInSAR acquisition mode, the system is able to measure several thousands of points in "near-realtime" with a minimal observation frequency of one image every few minutes. This capability represents an effective monitoring tool supporting emergency management activities [59]. Measurement is planned of selected test sites is planned for 2020 .
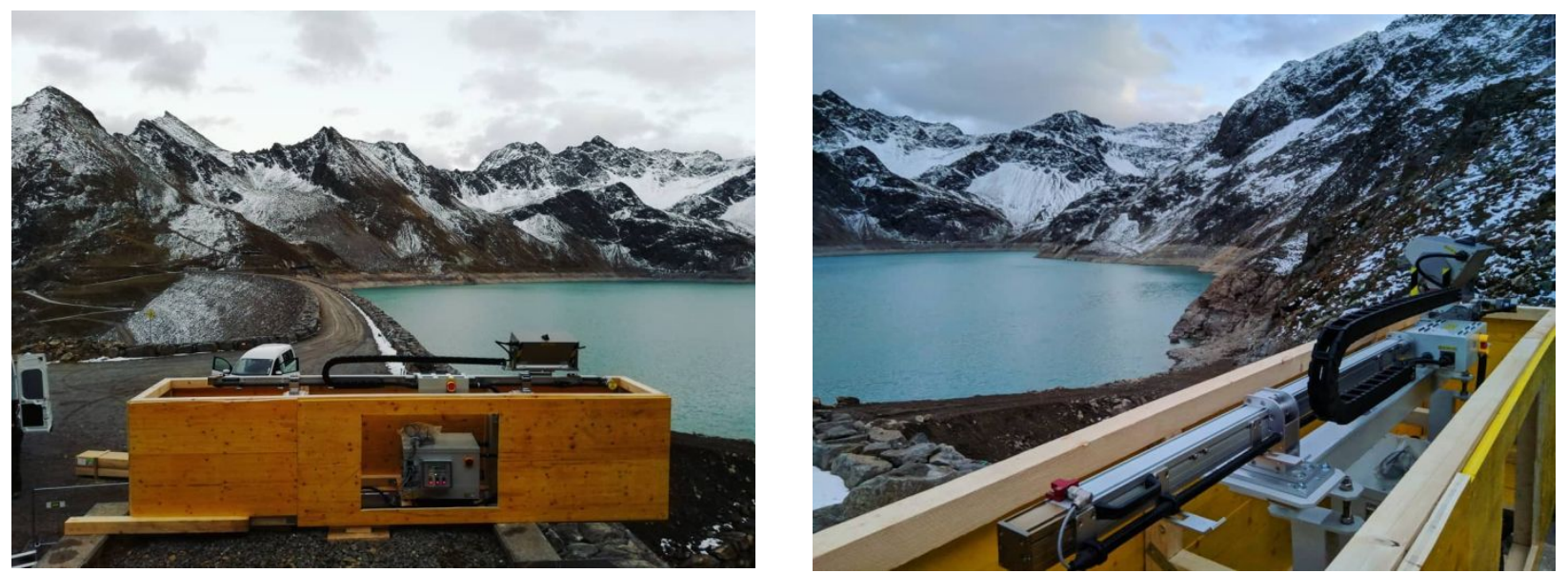

Figure 5 Installation of GBInSAR Lisamobile system in Kühtai (Tyrolia, Austria) from BOKU for testing Bild 5 Installation des GBInSAR- Systems im Kühtai (Tirol, Österreich) von der BOKU for testing 


\section{TLS / ALS}

In the last 20 years laser scanning techniques became an emerging method for topographic data acquisition. Compared to the direct and selective deformation monitoring by classical geodetic methods such as tachymetry or dGNSS, advances in laser scan technologies permit a detailed, area-wide and three-dimensional survey of terrain surfaces $[30,60]$. In contrast to imagery data laser scanning has the ability to penetrate through vegetation and acquire the earth surface below forests and scrublands. With national airborne laser scanning (ALS) flight campaigns it was possible for the first time to inventory and delineate landslides by their morphology (e.g. scarps, extension fractures) in areas covered by forest. The development of portable terrestrial laser scanners (TLS) enabled a flexible data acquisition on request. In 2011 a terrestrial long-range scanner (VZ-4000, Riegl) was introduced with scanning distances of up to $4000 \mathrm{~m}$ (Figure 6). Such large ranges facilitated the use of TLS for the monitoring of landslides. The combination of ALS data from national archives of area wide flight campaigns and TLS data allows direct multitemporal analyses about slope deformation after the first TLS measurement.

A prerequisite for successful laser scan based deformation measurements is that the landslide displacement between two measurement campaigns is higher than the data uncertainties. The uncertainties for laser scanning depend on the registration error, the surface roughness and the range depended positional uncertainties caused by the elongation of the laser beam [30]. Experiences from high alpine landslide monitoring projects in Tyrol have shown that the level of detection for multi-temporal long range TLS measurements with distances between slope and scanner of $500-2000 \mathrm{~m}$ vary between $0.05 \mathrm{~m}-0.15 \mathrm{~m}$. The level of detection for TLS campaigns depends on the scan settings (range, incidence angle, coverage) and the surface roughness. For ALS data the level of detection further depends on the strip adjustment, the calibration of GNSS/IMU (Inertial measurement unit) and the point density. The level of detection is higher than to TLS data ranges, which are between 0.15 and $0.3 \mathrm{~m}$ [60].

If the landslide activity exceeds the measurement uncertainties, multi-temporal laser scanning enables ongoing monitoring of the slope deformations and analyses of the landslide geometry and kinematics. The combination of different analyses methods (e.g. distance change and displacement analyses) allow the characterisation of different landslide processes and mechanisms (e.g. rockfall, sliding type, etc.), further to identify a different acceleration phase, and the subsequent formation and development of slabs. 


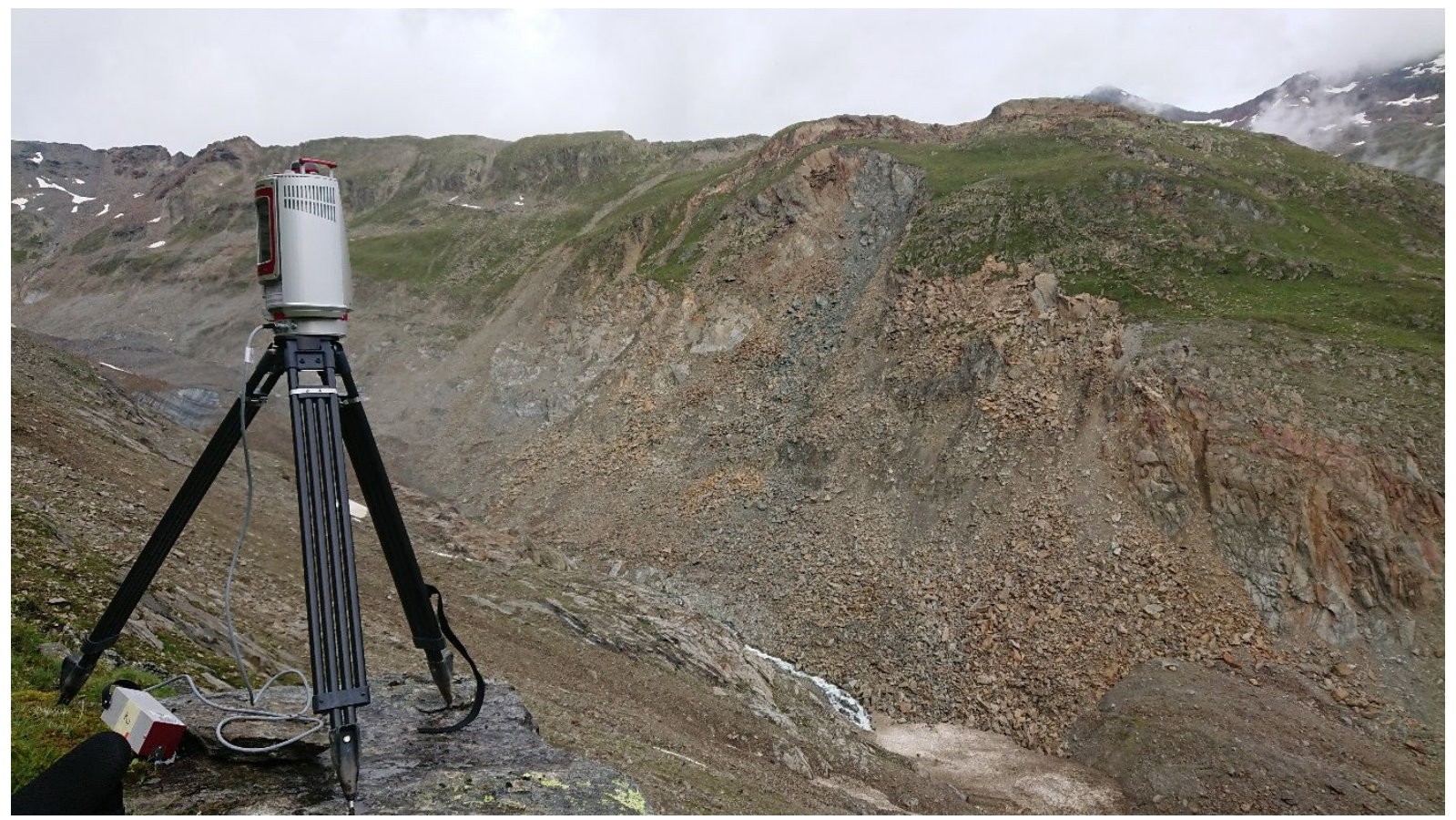

Figure 6 Terrestrial laser scan measurements of Marzellkamm $0.87 \mathrm{~km}$ across the opposite valley site

Bild 6 Terrestrischer Laserscan Vermessungen am Marzellkamm in 0.87 km Entfernung vom Gegenhang

\section{Extensometer}

An extensometer is a precision measuring device for displacement and deformation measurements between two points of interest [61]. For deformation monitoring of rock slope instabilities, surface extensometers are common measurement tools and have been applied in different case studies such as Ruinon, Valfurva (Italy) [62], Beauregard, Aosta Valley (Italy) [63], Hochmais-Atemkopf (Tyrol, Austria) [18], Gradenbach (Austria) [64] and Marzellkamm [29]. In order to understand the kinematics and deformation processes, i.e. the evolution of individual rock slide slabs, measurement sections are typically installed between a stable benchmark point and a control point within the rock slide mass. Measurement sections mounted across internal structures (e.g. trenches, horst and graben, step faults) give single point measurements and the internal deformation behaviour. At the Marzellkamm rock slide (Tyrol, Austria), two different types of contact-extensometers from GLÖTZL Baumesstechnik GesmbH have been implemented: (i) a fibre-glass rod extensometer for permanent (automatic) measurements (Figure 7a, 7b); and (ii) a convergence measuring device (tape extensometer) for periodic (manual) measurements (Fig. 7c, 7d).

The measuring principle of the fibre-glass rod extensometer is based on a tensioned rod, which permanently measures changes in length by a displacement transducer. The rod extensometer 
measures relative movements between the anchor point (stable benchmark point) and the measuring head (control point) within the moving mass. A surface mounted, polyethylene-cased fibre-glass rod is especially developed to eliminate common measurement problems in high alpine environment (e.g. wind gusts, ice and snow coverage, rock fall events, wild animals, etc.). The system is characterized by a measuring range of max. $250 \mathrm{~mm}$ and a measuring distance of max. $45 \mathrm{~m}$ between the detachment plane and a rock boulder within the sliding rock mass (Fig. 7a, 7b). If the end of the measuring range is reached, a slackening of the threaded rod at the anchor point causes the fibre-glass to contract again so that the displacement transducer returns to its initial position. This allows to use the measuring range beyond its max. measuring range, which is important for active rock slope instabilities. The measuring range and measuring distance of the Glötzl fibre-glass rod extensometer can be equipped according to the field of application. The measuring accuracy depends on the length of measuring distance, e.g. $0.02 \mathrm{~mm}$ for $20 \mathrm{~m}, 0.10 \mathrm{~mm}$ for $50 \mathrm{~m}, 0.30 \mathrm{~mm}$ for $100 \mathrm{~m}$ [65]. Due to the thermal expansion coefficient $\alpha$ of the fibreglass of $6.7 \times 10^{-6} / \mathrm{K}^{-1}$, temperature effects of a couple of $\mathrm{mm}$ have to be considered [65]. Displacement, internal temperature and battery voltage are automatically recorded with an on-site data logger. The battery life of the data logger is up to 5 years [66], in high alpine environment approx. up to 2 years. For manual data readout, either a USB interface or a Bluetooth module is available. A remote-control of the system is given by the application of the monitoring functionality by interaction with a GNSS/UTMS (3G) modem or a GLL server [66].

An alternative measurement method pictures the convergence measuring device (tape extensometer), which is a compact, portable and easy-handled tool to measure distances between fixed permanent bolts on rock surfaces (Fig. 7c, 7d). A consistent tension that is given to a measuring tape provides an accurate reading of the distance between the rock bolts (Fig. 7d). Periodic repetitive measurements over time record the displacements between the bolts in reference to each other. The GLÖTZL tape extensometer can be equipped with a measuring steel tape of 20 or $30 \mathrm{~m}$ length, and either a mechanical dial gauge or a digital measuring unit. The steel measuring tape is characterized by a longitudinal deformation coefficient $\alpha_{\mathrm{L}}$ of $10.2 \times 10^{-6} \mathrm{~m} /{ }^{\circ} \mathrm{C}$ [67]. Hence, temperature effects have to be taken into account as well. The measuring accuracy is about $\pm 0.05 \mathrm{~mm}$ for a distance up to $5 \mathrm{~m}$ and $\pm 0.1 \mathrm{~mm}$ for a distance of more than $5 \mathrm{~m}$ [67]. At the Marzellkamm rock slide the convergence measuring device consisting of a $30 \mathrm{~m}$ long measuring steel tape and a mechanical dial gauge was applied (Fig. 7c, 7d). 


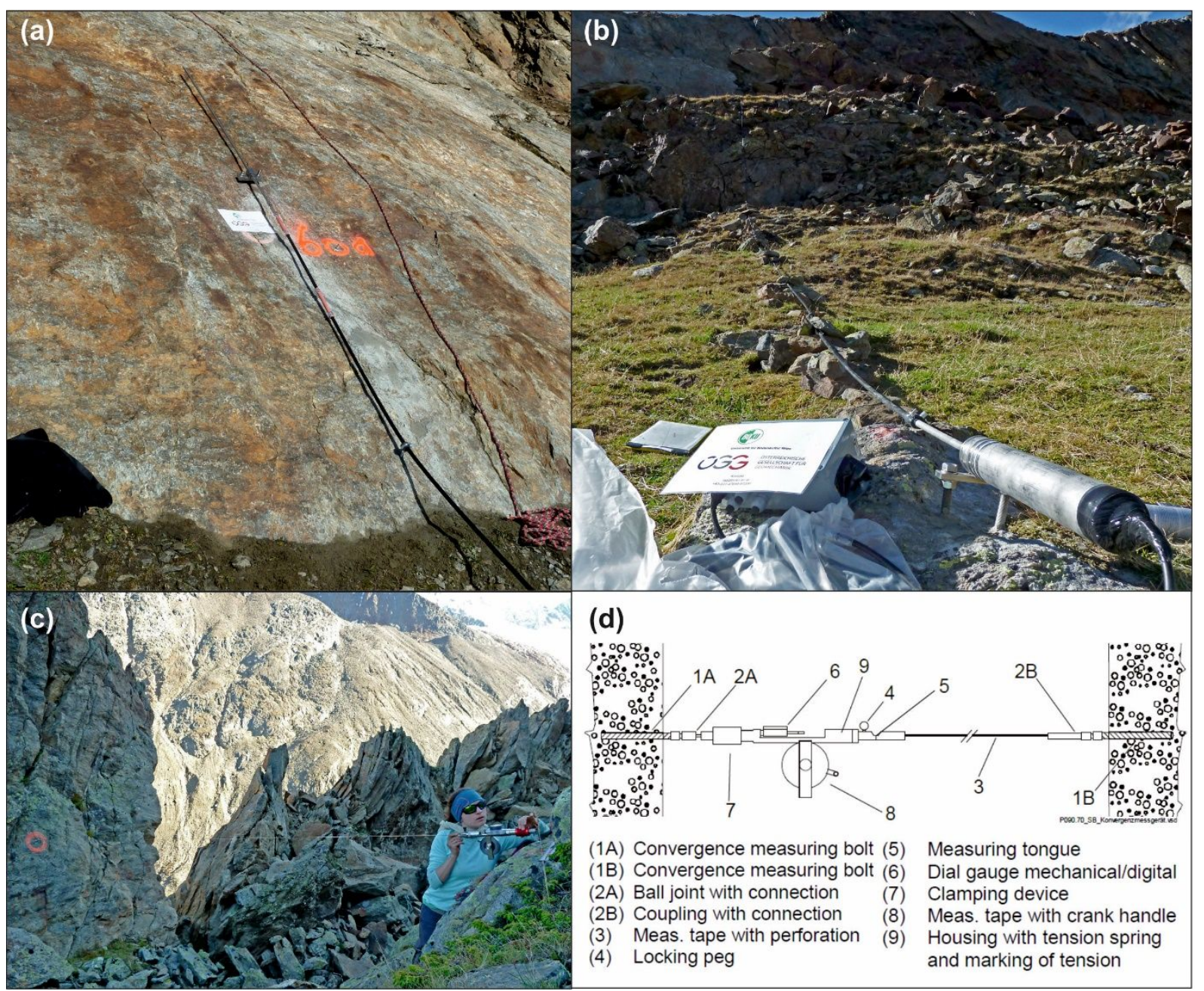

Figure 7 Application of two types of extensometers at the deep-seated Marzellkamm rock slide in Tyrol (Austria): The fiberglas rod extensometer measures permanently displacements between (a) anchor point at the detachment plane and (b) the measuring head at the rock boulder located within the sliding rock mass; The convergence measuring device is used for periodic repetitive measurements of displacements, e.g. (c) for measuring the width of the trench. (d) The measuring principle of the GLÖTZL convergence measuring device (tape extensometer) [67].

Bild 7. Einsatz von zwei Extensometern an der tiefgründigen Felsgleitung am Marzellkamm in Tirol (Österreich): Der Fiberglas-Stangen-Extensometer misst permanent Verschiebungen zwischen (a) dem Ankerpunkt in der Ablösefläche und (b) dem Messkopf am Felsbrocken der Gleitgesteinsmasse; Die Konvergenzmessvorrichtung wird für periodisch wiederkehrende Messungen von Verschiebungen eingesetzt, z.B. (c) zur Messung der Breite des Grabens. (d) Das Messprinzip des GLÖTZL-Konvergenzmessgerätes (Tape Extensometer) [60].

\section{UAS photogrammetry}

In recent years, the development of Unmanned Aerial System Photogrammetry (UAS-P) has provided a wide range of new possibilities for high resolution monitoring and mapping [68-70]. In general, UAS are able to bridge the gap between helicopter/airplane and terrestrial observations $[71,72]$. Aerial image acquisition with UAS combines high spatial resolution (sub-cm) with flexible acquisition options at a relatively low cost, making repeat missions and thus high temporal resolution feasible $[73,74]$. In this contribution, the term UAS refers to drones with a typical weight of $<5 \mathrm{~kg}$, flight times of 15-30 minutes, optimised for easy field deployment, recovery and

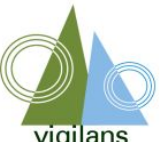


transport. The light weight, small size and compactness of many off-the-shelf UASs, results in a high operational range, allowing image acquisition over otherwise inaccessible areas, even when having to fly within visual line-of-sight $[75,76]$. This is reflected in the steadily growing number of reports on UAS applications for mapping different natural hazard processes, including mountain slope deformation [77, 78], landslides [79-82], rockfall [83, 84] and debris flow [21, 85]. The development of a wide range of (purpose-built) sensors available for use on-board UAS, has further added to their flexibility, e.g. allowing collecting multi- and hyperspectral imagery, LiDAR (light detection and range) and SAR data [86, 87].

Recent progress in the field of computer vision regarding Structure-from-Motion (SfM) and Multi View Stereopsis (MVS) have considerably reduced the requirements for aerial imagery to be used in photogrammetric processing [88-90]. SfM/MVS routines and tools are readily available in proprietary (e.g. Agisoft Megashape, PIX-4D) and open source (e.g. MicMac) software solutions [91]. They allow generating highly dense RGB-coloured 3D point clouds, as objects are tracked across image sequences from different view angles [76]; from these point clouds, Digital Surface Models (DSM) and orthophotos can be generated. These can in turn be used to calculate DEMs of Difference [92] to determine volume change, or to map the motion of features in orthophotos to measure surface velocity and direction between two UAS-acquisitions [93]. UAS-P studies with $60-80 \%$ overlapping images collected with different UAS and camera solutions delivered horizontal accuracy of 1-3 mm [94], vertical accuracy of $2.3 \mathrm{~cm}$ [73] and DEM resolutions of $2 \mathrm{~cm}$ [94]. Recent developments in the accuracy and precision of GNSS for UAS applications would still require a demonstration of their applicability to monitor slow slope deformations [69, 95-97].

In the scope of the project Vigilans [27] UAS-P was employed to monitor the active slope deformation Marzellkamm, situated in the upper Ötztal Valley (Figure 1). We acquired UAS imagery in August 2018 and 2019 with a drone (details of both campaigns in Table 2). The imagery was used to photogrammetrically compute orthophotos and DSMs (Figure 8, A-D) in Agisoft Metashape (v.1.5.3). We used IMCORR feature tracking (v. 1.1) [98, 99] in tiles of 64x64 pixels (approx. $5 \times 5 \mathrm{~m}$ ) with $128 \times 128$ pixel reference tiles for a correspondence analysis and horizontal displacement analysis of the DEM 2018 and 2019 (Figure 8, E).

The displacement vectors between 2018 and 2019 indicate surface displacements for the most active subdomain with velocities of 0.21-0.7 $\pm 0.05 \mathrm{~m} / \mathrm{a}$. This value is in excellent agreement with the values measured 2012-2018 indicating 0.2-0.3 m/a. A slower subdomain in the south of the 
Geomechanik und Tunnelbau Fachaufsatz/Bericht

slope deformation was measured with 0.05-0.25 m/a movement rates between 2012-2017. The repeated UAS-P 2018-2019 indicates 0.12-0.21 $\pm 0.05 \mathrm{~m} / \mathrm{a}$.

Table 2 Technical details of the 2018 and 2019 UAS-campaigns at the Marzellkamm study site.

Tabelle 2 Technische Details der UAS-Kampagnen 2018 und 2019 am Standort Marzellkamm

\begin{tabular}{l|l|l}
\hline Flight Date & 4 August 2018 & 6 August 2019 \\
\hline UAS Model & DJI Phantom 4 & DJI Phantom 4 RTK \\
\hline Camera Model (Focal Length) & FC330 $(3.61 \mathrm{~mm})$ & FC6310R $(8.8 \mathrm{~mm})$ \\
\hline Sensor Resolution [MP | PIX) & $12 \mid 4000 \times 3000$ & $20 \mid 5472 \times 3648$ \\
\hline No. Images & 1,366 & 1,202 \\
\hline Coverage Area & $0.43 \mathrm{~km}^{2}$ & $0.46 \mathrm{~km}^{2}$ \\
\hline Flying Altitude [m AGL] & 100 & 70 \\
\hline Number of GCPs & 32 & 6 \\
\hline GCP-Error XY | Z XYZ [m] & $0.04|0.04| 0.06$ & $0.04|0.04| 0.06$ \\
\hline
\end{tabular}


21 of 31 mechanik und Tunnelbau Fachaufsatz/Bericht
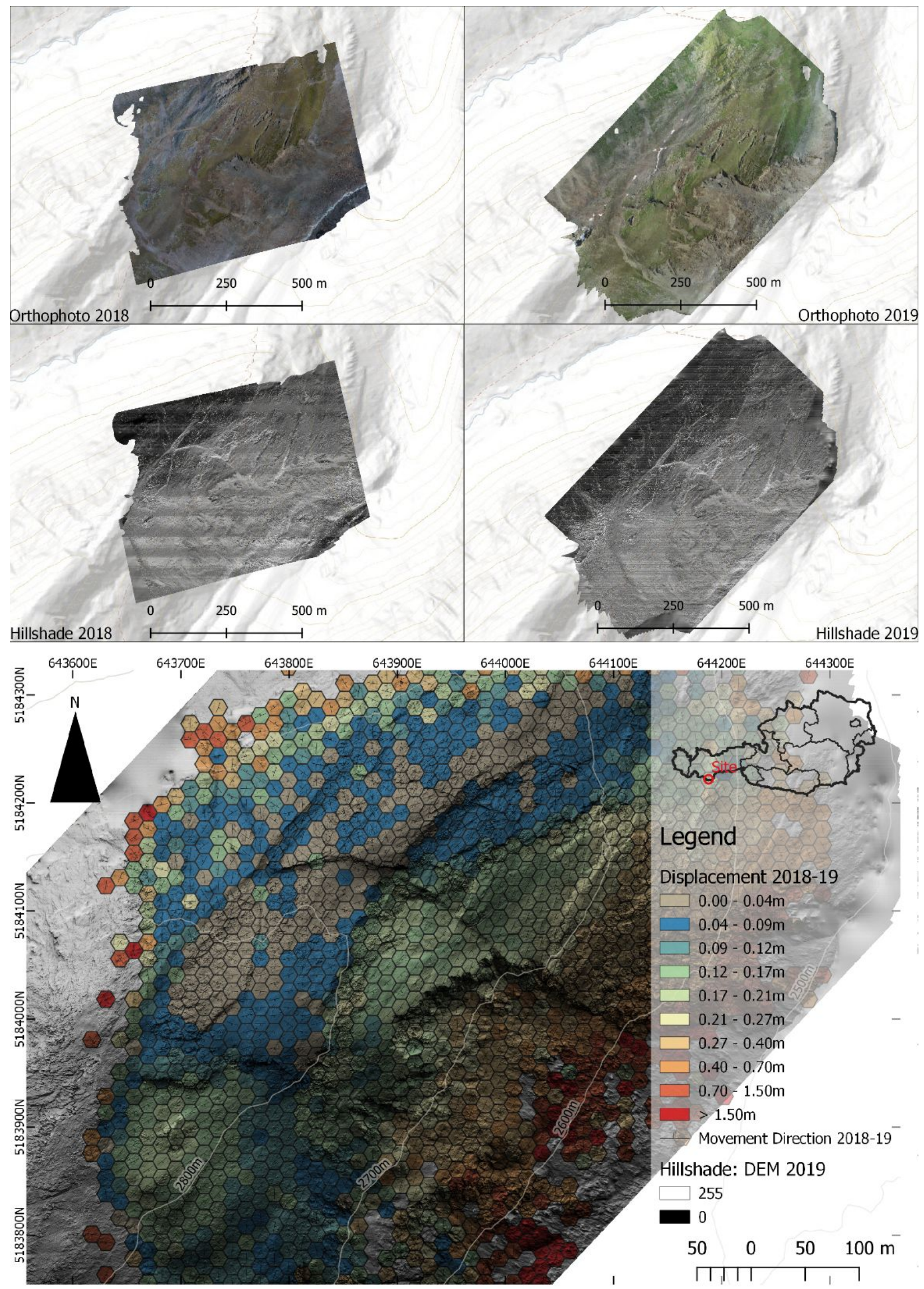

Figure 5 Results from the 2018 and 2019 UAS-P campaigns at Marzellkamm; (A) orthophoto 2018; (B) orthophoto 2019; (C) hillshaded DEM 2018; (D) hillshaded DEM 2019; (E) IMCORR displacement map. The Displacement map indicates displacement vector and velocities retrieved with feature

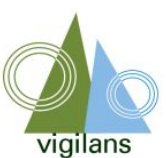


tracking. The values are represented with their arithmetic mean in hexagon grids to capture displacement. Displacement values at the edge of the DEM must not be used for analysis, since these values are only generated by distortion effects at the edges of 3D point clouds. Subdomains become clearly visible with the spatial distribution of displacement vectors and velocity patterns.

Bild 8 Ergebnisse der FH-P-Kampagnen 2018 und 2019 am Marzellkamm; (A) Orthophoto 2018; (B) Orthophoto 2019; (C) Schummerung DOM 2018; (D) Schummerung DOM 2019; (E) IMCORR Deformationskarte. Die Deformationskarte zeigt den Deformationsvektor und die Geschwindigkeiten an, die mit der „feature tracking“ Funktion abgerufen werden. Die Werte werden mit ihrem arithmetischen Mittel in Sechseck-Gittern dargestellt, um die Verschiebung zu erfassen. Verschiebungswerte am Rand des DEM dürfen für eine Analyse nicht verwendet werden, da diese Werte nur durch Verzerrungseffekte am Rand von 3D-Punktwolken erzeugt werden. Subdomänen werden durch die räumliche Verteilung von Verschiebungsvektoren und Geschwindigkeitsmustern deutlich sichtbar.

In general, the choice of the most appropriate UAS platform for mapping deep-seated rock slides and mountain slope deformations depends on the size of the area of interest (AOI). To cover small AOIs $(<1 \mathrm{~km})$, it is expedient to use rotor UAV; to map larger areas $\left(>1 \mathrm{~km}^{2}\right)$, a fixed-wing UAV is better suited. The main priority of flight planning must be safe UAS operation under challenging frame conditions, as the terrain may be hazardous and accessibility challenging. Minimum technical requirements for the UAS campaign (e.g. spatial resolution or image overlap), should be defined in the preparation phase, but should be conservative and given lower priority. Legislation regarding UAS-operation should be scrutinised. Depending on the national law, special rules may apply and additional certification might be necessary to fly over groups of people or in densely settled areas. The responsible national authorities may be able to provide a certificate of exemption in-case of emergencies.

\section{$5 \quad$ Need for comprehensive monitoring}

\section{Benefits and limitations of each method}

Temporally variable data is the key to both identifying unrecognized slope deformations for inventories [27], and improving the accuracy of the activity status within the inventories. Spatial data adds a further dimension to this understanding, allowing the recognition of domains within an active slope deformation. Spatial data have high precision but do not necessarily require a high resolution. InSAR from open access Sentinel-1 data has a 20x20 m ground resolution. This allows for the assignation of activity status and domains of slope deformations given the presupposition that the identified points by PSI or SBAS InSAR techniques are interpreted by experts and their plausibility is checked against available displacement measurements. We demonstrate this -with the application of fixed point survey time series to verify InSAR monitoring at the SaalbachHinterglemm test site [35]. Anomalous surface displacements can be recognised and further investigated with complimentary efforts to add higher resolution InSAR from TerraSAR-X time series $[100,101]$. 
Clustering of high surface displacement identified with Sentinel-1 can help to identify hot spots within slopes, which display considerable surface displacement [41, 102, 103]. In Norway and Italy the multi-temporal InSAR processing is increasingly an official part of landslide risk management and therefore recognized by administrative authorities [33, 35, 104]. It is important for users to recognize the limitations of the data, especially the fact that movement is recorded in 1D (LOS) and do not provide a kinematic solution. By decomposing multiple InSAR satellites and GB-InSAR it is possible to achieve a $2 \mathrm{D}$ or $3 \mathrm{D}$ surface vector $[105,106]$. Complimenting InSAR with subsurface data allows for the interpretation of more mechanical aspects of the slope deformation, i.e. coupled with piezometric records something may be said about seasonal displacements and hydromechanical behavior of the slope.

UAS-P allows for a high level of accuracy validated against extensometer and dGNSS data, with a lower displacement detection limit of $0.05 \mathrm{~m} / \mathrm{a}$. There is still room for improvement of the lower level of detection using lower elevation flight plans, real-time-kinematics for geographical correction, and improved flight planning software [107]. The potential to retrieve high resolution ground sampling of 1-2 cm is another advantage, especially in unstable or inaccessible terrain where the installation of fixed monitoring systems might be difficult or dangerous.

TLS measures deliver an excellent base to test the remote sensing data presented here with level of detection of $0.05-0.15 \mathrm{~m} / \mathrm{a}$ and has been validated as high-precision method in several studies [30, $108]$.

\section{Different applications for the data}

We present a suite of verifiable monitoring methods that are available to practitioners for the use of identifying and monitoring slope deformations. The coupling of different data series e.g. satellite and GBInSAR to obtain a movement vectors will enrich the understanding and conceptual model of a site. After detection of unrecognized slope deformations a combination of fixed point measurements with a high level of detection and spatial measurements are needed. Geology and geometry are of utmost importance for the determination of the total volume, the thickness of the slope movement and the identification of the movement subdomains. Field investigations of the surface and bedrock underground, engineering geological mapping, boreholes, exploration tunnels, geophysical investigations and extended deformation measurements, as well on the surface as in subsurface are necessary to understand the geology and geometry of the moving mass [11].

Potential kinematic failure mechanism of the slope is needed to classify the hazard, as the failure mechanisms determine the interaction of different subdomains with each other and therefore, the 
potential hazard class $[14,15]$. The failure mechanism can also influence the location of fixedpoint instrument placement (e.g. extensometers), as kinematic information is required for to determine the principal extensional axis. Extensometers are often implemented in tension features like cracks. The measurement data indicates the tensile strength of the rock mass, which is drastically lower than the rock mass shear strength. Therefore, measurements in tension cracks have a different meaning from that of shear failure surfaces e.g. gained from inclinometers within the rock mass. A spatial overview of the complete slope deformation site is therefore crucial before the installation of extensometers and other fixed point measurement systems.

Validated time series of slope deformation displacement rates are needed in order to identify potential acceleration and to meet the goals according to the Sendai Framework of preventing fatalities from landslides [109]. The results of the EU FP7 project SafeLand offer excellent guidelines on steps to be taken to detect and monitor different types of landslides $[26,74,110]$ and appropriate risk management system to deal with landslide risk [111].

The Vigilans project contributes towards the awareness of rapid acquisition and cost-efficient methods such as UAS-P, and the accessibility of processing and working methods in InSAR to contribute to a safer society in mountainous regions. In order to increase preparedness of the Austrian mountain society, a complete inventory of creeping slope deformations needs to be made, and can be done on a regional scale by remote sensing methods such as MSBAS InSAR using Sentinel-1, Envisat and TerraSAR-X satellite platforms. UAS-P and TLS/ALS can be used for cost-efficient spatial mapping and rapid characterization of the identified faster moving slope deformations, before instalment of well-established fixed-point measurement systems.

\section{Acknowledgements}

We were pleased with the very detailed and constructive criticism and feedback from both reviewers. They have contributed a lot to improve our manuscript. 


\section{Authors}

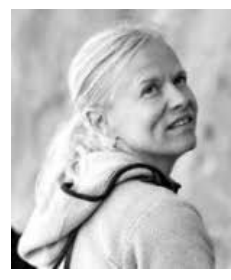

Prof. Dr. Anne Hormes

Sky4geo e.U.

Arctic University of Troms $\varnothing$

Planötzenhofstrasse 29b

Department of Geosciences

6020 Innsbruck

Postboks 6050 Langnes

ah@sky4geo.com

9037 Troms $ø$, Norway

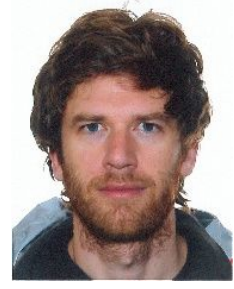

Mag. Marc Adams

Bundesforschungszentrum für Wald (BFW)

Institut für Naturgefahren

Rennweg 1

6020 Innsbruck

marc.adams@bfw.gv.at

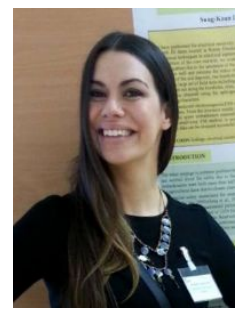

MSc. Anna Sara Amabile

Geologische Bundesanstalt (GBA)

Neulinggasse 38

1030 Wien

annaSara.Amabile@geologie.ac.at

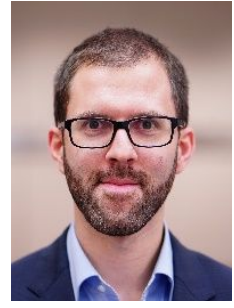

Dipl.Ing. Franz Blauensteiner

Leiter der Abteilung Grundlagen

Bundesamt für Eich-und Vermessungswesen (BEV)

Schiffamtsgasse 1-3

1020 Wien

franz.blauensteiner@bev.gv.at

Christian Demmler

Sky4geo e.U.

Planötzenhofstrasse 29b

6020 Innsbruck

christian.demmler@sky4geo.at

Dr. Christine Fey

University of Natural Resources and Life Sciences (BOKU) 
Geomechanik und Tunnelbau Fachaufsatz/Bericht

Institute for Applied Geology

Peter-Jordan-Strasse 82

1190 Wien

christine.fey@boku.ac.at

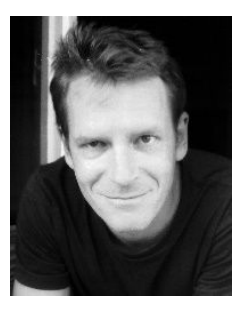

Dr. Marc Ostermann

Geologische Bundesanstalt (GBA)

Program coordinator for geomonitoring and disaster mitigation

Neulinggasse 38

1030 Wien

marc.ostermann@geologie.ac.at

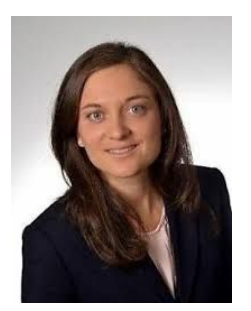

MSc. Christina Rechberger

University of Natural Resources and Life Sciences (BOKU)

Institute for Applied Geology

Peter-Jordan-Strasse 82

1190 Wien

christina.rechberger@boku.ac.at

Ing. Mag. Dr. Thomas Sausgruber

Wildbach- und Lawinenverbauung (WLV)

Geologische Stelle

Wilhelm-Greil-Strasse 9

6020 Innsbruck

thomas.sausgruber@die-wildbach.at

MSc. Filippo Vecchiotti

Geologische Bundesanstalt (GBA)

Engineering geology

Neulinggasse 38

1030 Wien

filippo.vecchiotti@geologie.ac.at

Dr. Eng. Geol. Louise M. Vick

Arctic University of Troms $\varnothing$ 


\section{Department of Geosciences}

Postboks 6050, Langnes

9037 Troms $\emptyset$, Norway

louise.m.vick@uit.no

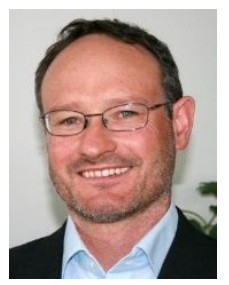

Univ.-Prof. Dr. Christian Zangerl, Universität für Bodenkultur Wien

University of Natural Resources and Life Sciences (BOKU)

Institute for Applied Geology

Peter-Jordan-Strasse 82

1190 Wien

christian.j.zangerl@boku.ac.at

\section{References}

[1] O. HungR, S. LeRoueIL, L. PICARELli: The Varnes classification of landslide types, an update. In: Landslides 11 (2014), S. 167-194.

[2] M. SCHLEIER, R.I. HERMANNS, J. ROHN, J.C. Gosse: Diagnostic characteristics and paleodynamics of supraglacial rock avalanches, Innerdalen, Western Norway. In: Geomorphology 245 (2015), S. 23-39.

[3] A. BRAATHEN, L.H. BLIKRA, S.S. BERG, F. KARLSEN: Rock-slope failures in Norway; type, geometry, deformation mechanisms and stability. In: Norwegian Journal of Geology 84 (2004), S. 67-88.

[4] L.H. BlikRA, O. LongVA, A. BRAathen, E. AndA, J.F. DeHLS, K. Stalsberg: Rock slope failures in Norwegian Fjord areas: examples, spatial distribution and temporal pattern. . In: NATOpaper (2003).

[5] F. Agliardi, G.B. Crosta, P. FrattinI, Landslides. Types, Mechanisms and Modeling., Cambridge University Press, Cambridge, 2012, pp. 207-221.

[6] G. CROSTA, P. FRATTINI, F. AgLIARDI: Deep seated gravitational slope deformations in the European Alps. In: Tectonophysics 605 (2013), S. 13-33.

[7] EEA_TECHNICAL_REPORT, Mapping the impacts of natural hazards and technological accidents in Europe, European Environmental Agency, Copenhagen, 2010, p. 144.

[8] E. EBERHARDT: The Hoek-Brown Failure Criterion. In: Rock Mechanical Engineering 45 (2012), S. 981-988.

[9] E. EberhARdt, D. SteAd, J.J.I.J.o.R.M. Coggan, M. ScIences: Numerical analysis of initiation and progressive failure in natural rock slopes—the 1991 Randa rockslide. In: 41 (2004), S. 69-87.

[10] K. TERZAGHI: Stability of steep slopes on hard unweathered rock. In: Geotechnique 12 (1962), S. 251-270.

[11] C. Zangerl, C. Prager, R. Brandner, E. Brückl, S. Eder, W. Fellin, E. Tentschert, G. Poscher, H.J.G.A. SCHÖNLAUB: Methodischer Leitfaden zur prozessorientierten Bearbeitung von Massenbewegungen. In: 5 (2008), S. 1-51.

[12] G.B. Crosta, F. Agliardi, C. Rivolta, S. Alberti, L. Dei CAS: Long-term evolution and early warning strategies for complex rockslides by real-time monitoring. In: Landslides 14 (2017), S. 1615-1632.

[13] E. Intrieri, F. Raspini, A. Fumagalli, P. Lu, S. Del Conte, P. Farina, J. Allievi, A. Ferretti, N.

CASAGLI: The Maoxian landslide as seen from space: detecting precursors of failure with Sentinel- 1 data. In: Landslides (2017).

[14] R.L. Hermanns, T. Oppikofer, E. Anda, H. Berg, L.H. Blikra, M. BÖHme, H. BunkHOLt, G.B. CROStA, H. DAHLE, L. FISCHER, M. JABOYEDOFF, S. LOEW, F. YUGSI MolinA, Recommended hazard and risk classification for large unstable rock slopes in Norway. , NGU rapport 2012, p. 53.

[15] R.L. HeRmanns, T. Oppikofer, F.X.Y. Molina, J.F. DeHLS, M. BÖHME, Landslide science for a safer geoenvironment, Springer, 2014, pp. 129-134.

[16] M. Ostermann, D. SANDERS, in: E. Eberhardt, C. Froese, K. Turner, S. Leroueil (Eds.), Landslides 
and Engineered Slopes. Protecting Society through Improved Understanding., Boca Raton, 2012, pp. 659663.

[17] EEA1/2017, Climate change, impacts and vulnerability in Europe 2016. An indicator-based report., European Environment Agency, Luxembourg, 2017.

[18] C. ZANGeRL, E. EbeRHARDT, S. PeRZLMAIER: Kinematic behaviour and velocity characteristics of a complex deep-seated crystalline rockslide system in relation to its interaction with dam reservoir. In:

Engineering Geology 112 (2010), S. 53-67.

[19] N. Casagli, F. Guzzetti, M. Jabozedoff, F. Nadim, D. Petley, in: K. Poljanšek, M. Marin Ferrer, T. De Groeve, I. Clark (Eds.), Science for disaster risk management 2017: knowing better and losing less. Disaster Risk Management Knowledge Centre, Publications Office of the European Union, Luxembourg, 2017.

[20] M.S. Adams, Y. BüHler, R. Boesch, R. Fromm, A. Stoffel, C. GinzleR, Investigating the Potential of Low-Cost Remotely Piloted Aerial Systems for Monitoring the Alpine Snow Cover (RPAS4SNOW). , Final Project Report, ÖAW - Austrian Academy of Sciences, Innsbruck, 2016, p. 82.

[21] M.S. AdAmS, R. FROMm, V. LECHNER, High-Resolution Debris Flow Volume Mapping with Unmanned Aerial Systems (UAS) and Photogrammetric Techniques. , in: R.S.a.S.I.S. The International Archives of the Photogrammetry (Ed.), XXIII ISPRS Congress, 12-19 July 2016, Prague, Czech Republic, 2016.

[22] L. KRISTENSEN, L.H. BLIKRA, Monitoring displacement on the Mannen rockslide in western Norway., Landslise Science and Practice, 2013, pp. 251-256.

[23] G. GRøNeng, H.H. ChRISTIANSEN, B. NILSEN, L.H.J.L. BLIKRA: Meteorological effects on seasonal displacements of the Åknes rockslide, western Norway. In: 8 (2011), S. 1-15.

[24] NVE: Fjellskredovervaking. URL https://www.nve.no/flaum-ogskred/fjellskredovervaking/?ref=mainmenu. mailto:Author Address| - Publisher|.

[25] F. BARDI, F. RASPINI, A. CIAMPALINI, L. KRISTENSEN, L. ROUYET, T.R. LAUKNES, R. FRAUENFELder, N. CASAGLI: Space-borne and ground-based InSAR Data integration: the Åknes test site. In: remote sensing 8 (2016), S. 237.

[26] S. Bazin, J. Malet, E. Damiano, L. Picarelli, S. Cardellini, E. Garbarino, A. Gozzi, M. Lovisolo, I. BARON, B.J.D.D. JOCHUM: Guidelines for landslide monitoring and early warning systems in Europe-design and required technology. In: 8 (2012).

[27] VIGILANS: Monitoring slope deformations with InSAR and unmanned aerial vehicle photogrammetry. URL https://projekte.ffg.at/projekt/2977055. - Aktualisierungsdatum: 24-09-2019. mailto:Author Address| Publisher|.

[28] C. FEY, V. WICHMANN, C. ZANGERL: Reconstructing the evolution of a deep seated rockslide (Marzell) and its response to glacial retreat based on hitoric and remote sensing data. In: Geomorphology 298 (2017), S. 72-85.

[29] C. ReChBERGER, C. ZANGERL, C. Fey, Geology, geometry and kinematics of an active deep-seated rock slide (Ötztal valley, Austria). 47. Geomechanics-Colloquium NOV 16, 2018, Veröffentlichungen des Instituts fur Geotechnik der TU Bergakademie Freiberg, Freiberg, 2018, pp. 135-156.

[30] C. FEY, V. WICHMANN, LANDFORMS: Long-range terrestrial laser scanning for geomorphological change detection in alpine terrain-handling uncertainties. In: Journal of Earth Surface Processes 42 (2017), S. 789-802.

[31] B.F. INNERES, SKKM Staatliches Krisen- und Katastrophenschutzmanagement. Strategie 2020., 2009 , p. 22.

[32] J. OTTER, E. IMREK, S. MELZNER, Geodätische Grundlagenvermessung als Werkzeug in der Naturgefahrenanalyse. , in: I. Wimmer-Frey, A. Römer, C. Janda (Eds.), Angewandte Geowissenschaften an der GBA, Wien, 2017, pp. 147-152.

[33] G. Løvø: Lansering av InSAR Norge. URL https://www.ngu.no/aktiviteter/lansering-av-insar-norge. Aktualisierungsdatum: 23-09-2019. mailto:Author Address| - Publisher|.

[34] M. Costantini, A. Ferretti, F. Minati, S. Falco, F. Trillo, D. Colombo, F. Novali, F. Malvarosa, C. MAMMONE, F.J.R.S.O.E. VECCHIOLI: Analysis of surface deformations over the whole Italian territory by interferometric processing of ERS, Envisat and COSMO-SkyMed radar data. In: 202 (2017), S. 250-275. [35] M. Del Soldato, L. Solari, F. Raspini, S. Bianchini, A. Ciampalini, R. Montalti, A. Ferretti, V. PelLegrineschI, N. CASAGLI: Monitoring Ground Instabilities Using SAR Satellite Data: A Practical 
Approach. In: ISPRS Journal of Geo-Information 8 (2019), S. 307.

[36] D. CALCATERRA, M. RAMONDINI: Assessing the activity of a large landslide in Southern Italy by ground-and SAR Interferometric techniques. In: (2010).

[37] C. DeL VeNTISETTE, G. RIGHINI, S. MORETTI, N. CASAGLI: Multitemporal landslides inventory map updating using spaceborne SAR analysis. In: International Journal of Applied Earth Observation and Geoinformation 30 (2014), S. 238-246.

[38] A. Ferretti, A. Monit-Guarnieri, C. Prati, F. Rocca, InSAR Principles: Guidelines for SAR Interferometry Processing and Interpretation., in: E.S. Agency (Ed.), 2007.

[39] A. FERRETTI, C. PRATI, F. ROCCA: Nonlinear subsidence rate estimation using permanent scatterers in differential SAR interferometry. In: IEEE Transactions on Geoscience and Remote Sensing 38 (2000), S. 2202-2212.

[40] F. MEYER, The SAR Handbook., SERVIR Global Science Coordination Office, National Space Science and Technology, Huntsville, 2019, pp. 21-43.

[41] L. ROUYET, T.R. LAUKNES, K.A. HøGDA, Spaceborne radar interferometry (InSAR) for natural hazards, landslides and infrastructure: limitations and potential., in: N. InSAR (Ed.), Norut, 2015, p. 76.

[42] C. BARBOUX, R. DELALOYE, C. LAMBIEL: Inventorying slope movements in an Alpine environment using DInSAR. In: Earth surface processes and landforms 39 (2014), S. 2087-2099.

[43] C. Barboux, T. Strozzi, R. Delaloye, U. Wegmüller, C. Collet: Mapping slope movements in Alpine environments using TerraSAR-X interferometric methods. In: ISPRS journal of photogrammetry and remote sensing 109 (2015), S. 178-192.

[44] C. ZHAO, Z. LU, Remote sensing of landslides-A review, Multidisciplinary Digital Publishing Institute, 2018.

[45] S.V. SAMSONOV, N. D'OREYE: Multidimensional small baseline subset (MSBAS) for two-dimensional deformation analysis: Case study Mexico City. In: Canadian Journal of Remote Sensing 43 (2017), S. 318329.

[46] F. CIGNA, L.B. BEATESON, C.J. JORDAN, C. DASHWOOD: Simulating SAR geometric distortions and predicting Persistent Scatterer densities for ERS-1/2 and ENVISAT C-band SAR and InSAR applications: Nationwide feasibility assessment to monitor the landmass of Great Britain with SAR imagery. In: Remote Sensing of Enviornment 152 (2014), S. 441-466.

[47] S. PLANK, A. TWELE, S. MARTINIS: Landslide mapping in vegetated areas using change detection based on optical and polarimetric SAR data. In: Remote Sensing 8 (2016), S. 307-.

[48] F. VECCHIOTTI, D. PEdUTO, T. StROZZI, Multi-sensor a Priori PSI visibility map for nationwide landslide detection in Austria., 4th World Landslide Forum, Springer International, Ljubljana, 2017, pp. 4552.

[49] A. HOOPER, D. BEKAERT, K. SPAANS, M. ARIKAN: Recent advances in SAR interferometry time series analysis for measuring crustal deformation. In: Tectonophysics (2012), S. 514-517.

[50] S.V. SAMSONOV: User manual, source code, and test set for MSBASv3 (Multidimensional Small Baseline Subset version 3) for one- and two-dimensional deformation analysis. In: Geomatics Canada Open File 45 (2019).

[51] A. Barra, L. Solari, M.M. Pizarro, O. Monserrat, S. Bianchini, G. Herrera, M. Crosetto, R. SarRo, E. González-Alonso, R. MAteos, S. LigüerzanA, C. López, S. Moretti: A Methodology to Detect and Update Active Deformation Areas Based on Sentinel-1 SAR Images In: Remote Sensing 9 (2017), S. 1002.

[52] C. COLESANTI, J. WASOWSKI: Investigating landslides with space-borne Synthetic Aperture Radar (SAR) interferometry. In: Engineering Geology 88 (2006), S. 173-199.

[53] L. CASCINI, G. FoRNARO, D. PEDUTO: Advanced low- and full-resolution DInSAR map genera-tion for slow-moving landslide analysis at different scales. In: Engineering Geology 112 (2010), S. 29-42.

[54] F. Cigna, C. Del VentisetTe, V. LIGUORI, N. CASAGLI: Advanced radar-interpretation of InSAR time series for mapping and characterization of geological processes. In: Natural Hazards and Earth System Sciences 11 (2011), S. 865- 881.

[55] L. Rouyet, L. KRISTEnsen, M.-H. DeRron, C. Michoud, L.H. BlikRA, M. JabOyedoff, T.R. Lauknes:

Evidence of rock slope breathing using ground-based InSAR. In: Geomorphology xxx (2017).

[56] O. MONSERRAT, M. CROSETTO, G. LUZI: A review of ground-based SAR interferometry for 
deformation measurement. In: ISPRS Journal of Photogrammetry and Remote Sensing 93 (2014), S. 40-48.

[57] D. TARCHI, N. CASAGLI, S. MoretTI, D. LeVA, A.J. SIEBER: Monitoring landslide displacements by using ground-based synthetic aperture radar interferometry: Application to the Ruinon landslide in the Italian Alps. In: Journal of Geophysical Research 108 (2003), S. 2387.

[58] LISALAB. URL http://www.lisalab.com/home/. mailto:Author Address| - Publisher|.

[59] N. CASAGLI, P. FARINA, D. LEVA, G. NICO, D. TARCHI, Ground-based SAR interferometry as a tool for landslide monitoring during emergencies, IGARSS 2003. 2003 IEEE International Geoscience and Remote Sensing Symposium. Proceedings (IEEE Cat. No. 03CH37477), IEEE, 2003, pp. 2924-2926.

[60] C. FEY: Remote sensing applications for deformation monitoring of landslides in alpine environment. . University of Innsbruck, Institute of Geography, 2018

[61] C. Huston: The Effect of Continued and Progressively Increasing Strain upon Iron. In: Journal of the Franklin Institute 107 (1879), S. 41-44.

[62] G.B. CROSTA, F. AGLIARDI: How to obtain alert velocity thresholds for large rockslides. In: Physics and Chemistry of the Earth 27 (2002), S. 1557-1565.

[63] G. BARLA, F. Antolini, M. BARLA, E. MENSI, G. PIovano: Monitoring of the Beauregard landslide (Aosta Valley, Italy) using advanced and conventional techniques. . In: Engineering Geology 116 (2010), S. 218-235.

[64] E. BRÜCKL, F.K. BRunner, E. LANG, S. MertL, M. MÜLleR, U. StARY: The Gradenbach Observatory monitoring deep-seated gravitational slope deformation by geodetic, hydrological, and seismological methods. In: Landslides (2013).

[65] GLÖTZL, GKTE 16 Fiberglas rod extensometer. P_60.10_Extensometer_GKTE_en.pdf, in: GLÖTZL_Baumesstechnik_GesmbH (Ed.), Rheinstetten, Germany, 2017.

[66] GLÖTZL, DL Datenlogger. P_53.80_Datenlogger_DL_de.pdf, in:

GLÖTZL_Baumesstechnik_GesmbH (Ed.), Rheinstetten, Germany, 2014.

[67] GLÖTZL, Convergence measuring device - System Behensky/Glötzl.

P090.70.01.00.00.001R05_engl.docx, in: GLÖTZL_Baumesstechnik_GesmbH (Ed.), Germany, 2010.

[68] I. COLOMINA, P. MolinA: Unmanned aerial systems for photogrammetry and remote sensing: A review. In: ISPRS Journal of Photogrammetry and Remote Sensing 92 (2014), S. 79-97.

[69] C. Tотн, G. Jozkow: Remote sensing platforms and sensors: A survey. In: ISPRS Journal of Photogrammetry and Remote Sensing 115 (2016), S. 22-36.

[70] G. PAJARES: Overview and Current Status of Remote Sensing Applications Based on Unmanned Aerial Vehicles (UAVs). . In: Photogrammetric Engineering and Remote Sensing 81 (2015), S. 281-330.

[71] C. BRIESE, R. Fortner, P. SAgER, N. PFEIFER: Vom Modellflughobby zu unbemannten Flugsystemen für die Geodatenerfassung. . In: Österreichische Zeitschrift für Vermessung und Geoinformation (VGI) 101 (2013), S. 64-74.

[72] T. RosnelL, E. HonkAVAARA: Point cloud generation from aerial image data acquired by a quadrocopter type micro unmanned aerial vehicle and a digital still camera. . In: Sensors 12 (2012), S. 453480.

[73] F. NeX, F. Remondino: UAV for 3D mapping applications: a review. In: Applied Geomatics 6 (2014), S. 1-15.

[74] V. TOFANI, S. SEgONI, F. CATANAI, N. CASGLI, Evaluation report on innovative monitoring and remote sensing methods and future technology., SafeLand - Living with landslide risk in Europe: assessment, effects of global change and risk management strategies., UNIFI, Universita degli Studi di Firenze, 2011.

[75] M. SCAIONI, L. LONGONI, V. MELILLO, M. PAPINI: Remote Sensing for Landslide Investigations: An Overview of recent achievements and perspectives. In: remote sensing 6 (2014), S. 1-53.

[76] A. Elther, A. Kaiser, C. CAstillo, G. Rock, F. Neugirg, A. Abellan: Image-based surface reconstruciton in geomorphometry - merits, limits and developments. In: Earth Surface Dynamics 4 (2016), S. 359-389.

[77] M. RUSNÁK, J. SLÁDEK, J. BUŠA, V. GREIF: Suitability of digital elevation models generated by uav photogrammetry for slope stability assessment (case study of landslide in Svätý Anton, Slovakia). In: Acta Scientiarum Polonorum Formatio Circumiectus (15 (2016), S. 439-450.

[78] M.S. Kovacevic, M. Car, M. Bacic, I. Stipanovic, K. Gavin, K. Noren-Cosgriff, A. Kaynia, (2018). Report on the use of remote monitoring for slope stability assessments D1.4. Report from the H2O2O project 
DESTination RAIL -Decision Support Tool for Rail Infrastructure Managers. In: (2018).

[79] D. TURner, A. LUCIEER, S. DE Jong: Time Series Analysis of Landslide Dynamics Using an Unmanned Aerial Vehicle (UAV). In: Remote Sensing 7 (2015), S. 1736.

[80] T. Fernández, J.L. Pérez, F.J. Cardenal, A. López, J.M. Gómez, C. Colomo, J. Delgado, M. SÁNCHEZ: Use of a light UAV and photogrammetric techniques to study the evolution of a landslide in Jaén (southern Spain). . In: ISPRS Archives XL-3/W3 (2015), S. 241-248.

[81] U. Niethammer, M.R. James, S. Rothmund, J. TRAVEllettI, M. JoswiG: UAV-based remote sensing of the Super-Sauze landslide: evaluation and results. In: Engineering Geology 128 (2012), S. 2-11.

[82] A. StumpF, J.-P. MAlet, N. KeRLE, U. Niethammer, S. Rothmund: Image-based mapping of surface fissures for the investigation of landslide dynamics. In: Geomorphology 186 (2013), S. 12-27.

[83] D. Giordan, A. Manconi, A. Facello, F. Baldo, M. dell'Anese, P. Allasia, F. Dutto: Brief Communication: The use of an unmanned aerial vehicle in a rockfall emergency scenario. . In: Natural Hazards and Earth System Sciences 15 (2015), S. 163-169.

[84] M. DANZI, G.D. CRESCENZO, M. RAMONDINI, A. SANTO: Use of unmanned aerial vehicles (UAVs) for photogrammetric surveys in rockfall instability studies. In: Red. Online Soc. Geol. It. (2012).

[85] B. SOTIER, A. GRAF, J. KammERLANDER: Einsatz von UAV im alpinen Gelände: Erfahrungsbericht und Anwendungsbeispiel aus der Naturgefahrenpraxis. . In: Österreichische Zeitschrift für Vermessung und Geoinformation (VGI) 101 (2013), S. 110-118.

[86] Y. LIN, J. HYYPPÄ, A. JAAKKOLA: Mini-UAV-borne LIDAR for fine-scale mapping. In: IEEE Geoscience and Remote Sensing Letters 8 (2011), S. 426-430.

[87] S. HENSLEY, K. WHEELER, G. SADOWY, The UAVSAR instrument: description and first results., roceedings of the IEEE Radar Conference (RADAR '08), 1-6, Rome, Italy, May 2008, 2008.

[88] A. StumpF, J.P. MAlet, P. Allemand, M. PIERROT-DeseIlligny, G. SkUPINSKI: Ground-based multiview photogrammetry for the monitoring of landslide deformation and erosion. In: Geomorphology 231 (2015), S. 130-145.

[89] J.J. KoENDERINK, A.J. VAN DOORN: Affine structure from motion. In: JOSA A 8 (1991), S. 377-385.

[90] Y. FURUKAWA, J. PONCE: Accurate camera calibration from multi-view stereo and bundle adjustment. . In: International Journal of Computer Vision 84 (2009), S. 257-268.

[91] E. RUPNIK, M. DAAKIR, M.P. DESEILIGNY: MicMac - a free, open-source solution for photogrammetry. . In: Open Geospatial Data, Software and Standards 2 (2017), S. 14.

[92] R. WILLIAMS: DEMs of difference. In: Geomorphological Techniques, British Society for Geomorphology 2 (2012).

[93] S.D. JawaK, S. Kumar, A.J. Luis, M. Bartanwala, S. Tummala, A.C. Pandey: Evaluation of Geospatial Tools for Generating Accurate Glacier Velocity Maps from Optical Remote Sensing Data. In: Proceedings Prevention and mitigation of natural and anthropogenic hazards due to land subsidence 2 (2018), S. 341.

[94] A.S. WOODGET, R. AustRUMS: Subaerial gravel size measurement using topographic data derived from a UAV-SfM approach. In: Earth Surface Processes and Landforms 42 (2017), S. 1434-1443.

[95] M. SCAIONI, M. CORTI, G. DIOLAIUTI, D. FugAZZA, M. CERNUSCHI, Local and general monitoring of Forni glacier (Italian Alps) using multi-platform structure-from-motion photogrammetry., International Archives of he Photogrammetry, Remote Sensing and Spatial Information Sciences, Wuhan, China, 2017, pp. 1547-1554.

[96] R. SCHLÖGEL, B. THIEBES, I. TOSCHI, T. ZIEHER, M. DARVISHI, C. KofLER, Sensor data integration for landslide monitoring - the Lemonade concept., in: M.e.a. Mikos (Ed.), 4th World Landslide Forum, Springer International, Ljubljana, 2017, pp. 71-78.

[97] EGSA, GNSS Market Report - Surveying., in: E.G.N.S.S. Agency (Ed.), 2017.

[98] M. BREMER, IMCORR - Feature Tracking. SAGA module Reference. , http:www.saga-gis.org, 2012.

[99] O. ConRad, B. Bechtel, M. Bock, H. Dietrich, E. Fischer, L. GerlitZ, J. WeHBERg, V. Wichmann, J. BÖHNER: System for automated geoscientific analysis v. 2.1.4. In: Geoscientific Model Development 8 (2015), S. 1991-2007.

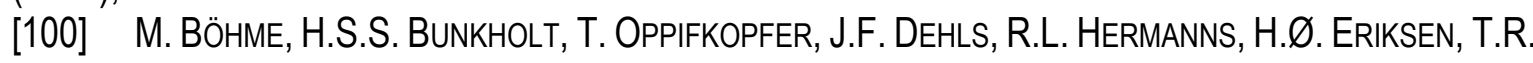
LAUKNES, in: A.e. al. (Ed.), Landslides and Engineered Slopes. Experience, Theory and Practice, Associazione Geotecnica Italiana, Rome, 2016. 
[101] T.R. Lauknes, A.P. ShankeR, J.F. Dehls, H.A. ZebKer, I.H.C. Henderson, Y. LARSEN: Detailed rockslide mapping in northern Norway with small baseline and persistent scatterer interferometric SAR time series methods. In: Remote Sensing of Environment 114 (2010), S. 2097-2109.

[102] F. RaspinI, S. BianchinI, A. Ciampalini, M. Del Soldato, R. Montalti, L. Solari, V. Tofani, N.J.L. CASAGLI: Persistent Scatterers continuous streaming for landslide monitoring and mapping: the case of the Tuscany region (Italy). In: (2019), S. 1-12.

[103] F. Raspini, A. Ciampalini, S. Del Conte, L. Lombardi, M. NocentinI, G. Gigli, A. Ferretti, N. CASAGLI: Exploitation of amplitude and phase of satellite SAR iages for Landslide mapping: the case of Montescaglioso (South Italy). In: 7 (2015), S. 14576-14596.

[104] I. NORGE. URL https://www.ngu.no/en/topic/insar-norway. mailto:Author Address| - Publisher|. [105] H.Ø. ERIKSEN, S.G. BERGH, Y. LARSEN, I. SKREDE, L. KRISTENSEN, T.R. LAUKNES, L.H. BLIKRA, H.P. KIERULF: Relating 3D surface displacement from satellite-and ground-based InSAR to structures and geomorphology of the Jettan rockslide, northern Norway. In: (2017).

[106] H.Ø. ERIKSEN, T.R. LAUKNeS, Y. LARSEN, G.D. CoRneR, S.G. BeRGH, J. DeHLS, H.P. KieRULF: Visualizing and interpreting surface displacement patterns on unstable slopes using multi-geometry satellite SAR interferometry (2D InSAR). In: Remote Sensing of Environment 191 (2017), S. 297-312.

[107] T.R. Chudley, P. Christoffersen, S.H. Doyle, A. ABelLAN, N.J.C. SNoOKE: High-accuracy UAV photogrammetry of ice sheet dynamics with no ground control. In: 13 (2019), S. 955-968.

[108] J.L. CARRIVICK, M.W. SMITH, D.M. CARRIVICK: Terrestrial laser scanning to deliver high-resolution topography of the upper Tarfala valley, Arctic Sweden. In: GFF 137 (2015), S. 383-396.

[109] UNISDR, Sendai Framework for Desaster Risk Reduction 2015 - 2030., in: U.N.O.f.D.R. Reduction (Ed.), Geneva, 2015, p. 37.

[110] R. SUPPER, I. BARON, Landslide Monitoring Technologies and Early Warning Systems. Current Research and Perspeectives for the Future., Berichte der Geologischen Bundesanstalt, Geological Survey of Austria, Wien, 2010, p. 69.

[111] A. StUMPF, N. KERLE, J.P. MALET, Guidelines for the selection of appropriate remote sensing technologies for monitoring different types of landslides, in: G.A. European Project SafeLand (Ed.), Deliverable 4.4, 2011, p. 91. 